
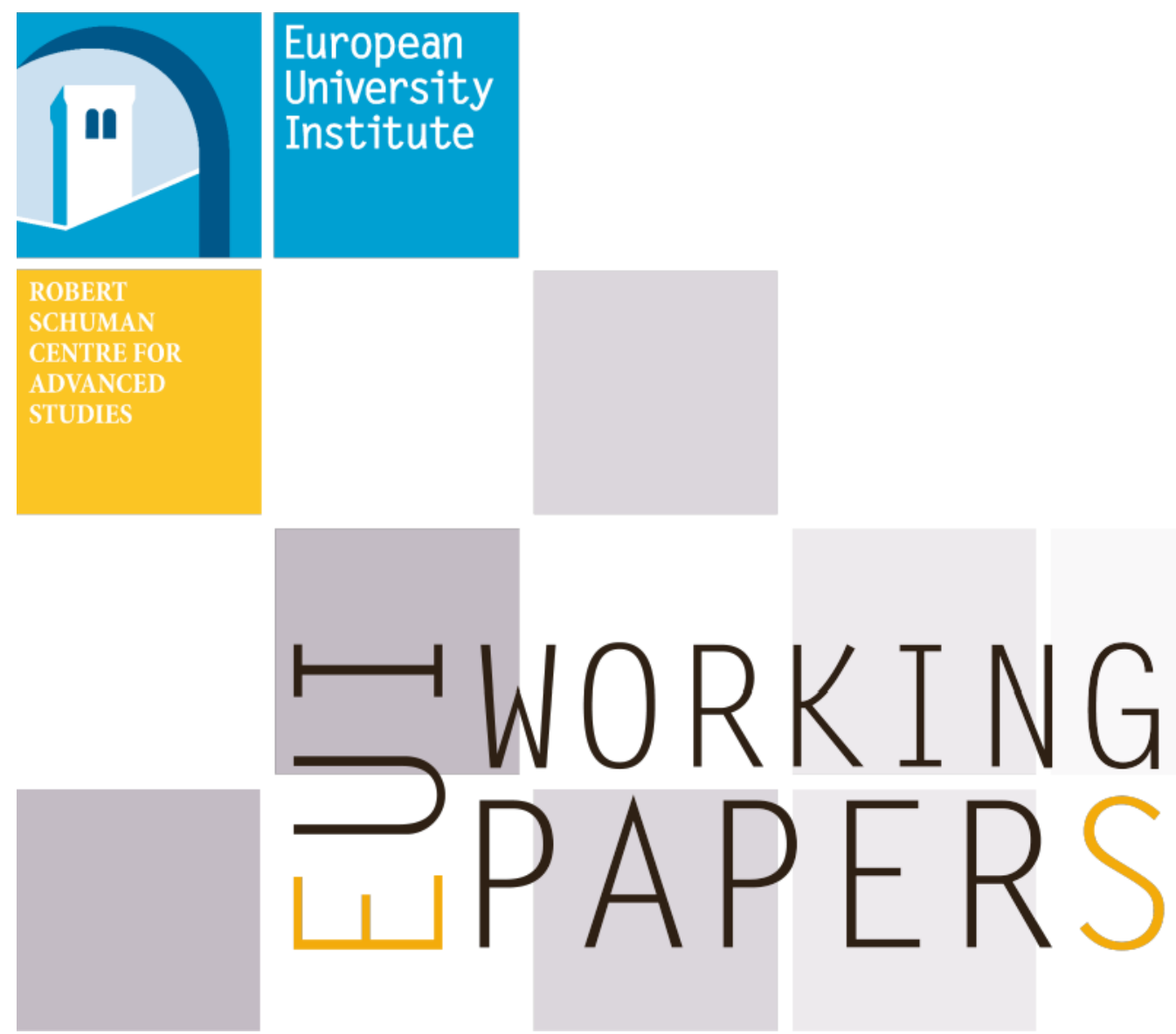

RSCAS 2020/90

Robert Schuman Centre for Advanced Studies

The European Governance and Politics Programme

Are Nationalists Better Citizens?

Lenka Dražanová and Andrew Roberts 

European University Institute

Robert Schuman Centre for Advanced Studies

The European Governance and Politics Programme

\section{Are Nationalists Better Citizens?}

Lenka Dražanová and Andrew Roberts

EUI Working Paper RSCAS 2020/90 
Terms of access and reuse for this work are governed by the Creative Commons Attribution 4.0 (CCBY 4.0) International license. If cited or quoted, reference should be made to the full name of the author(s), editor(s), the title, the working paper series and number, the year and the publisher.

ISSN 1028-3625

(C) Lenka Dražanová and Andrew Roberts, 2020

This work is licensed under a Creative Commons Attribution 4.0 (CC-BY 4.0) International license. https://creativecommons.org/licenses/by/4.0/

Published in December 2020 by the European University Institute.

Badia Fiesolana, via dei Roccettini 9

I - 50014 San Domenico di Fiesole (FI)

Italy

Views expressed in this publication reflect the opinion of individual author(s) and not those of the European University Institute.

This publication is available in Open Access in Cadmus, the EUI Research Repository:

https://cadmus.eui.eu 


\section{Robert Schuman Centre for Advanced Studies}

The Robert Schuman Centre for Advanced Studies, created in 1992 and currently directed by Professor Brigid Laffan, aims to develop inter-disciplinary and comparative research on the major issues facing the process of European integration, European societies and Europe's place in $21^{\text {st }}$ century global politics.

The Centre is home to a large post-doctoral programme and hosts major research programmes, projects and data sets, in addition to a range of working groups and ad hoc initiatives. The research agenda is organised around a set of core themes and is continuously evolving, reflecting the changing agenda of European integration, the expanding membership of the European Union, developments in Europe's neighbourhood and the wider world.

For more information: http://eui.eu/rscas

The EUI and the RSCAS are not responsible for the opinion expressed by the author(s).

\section{European Governance and Politics Programme}

The European Governance and Politics Programme (EGPP) is an international hub of high-quality research and reflection on Europe and the European Union. Launched in 2018, it is part of the research programmes of the Robert Schuman Centre for Advanced Studies at the European University Institute.

The EGPP maintains its core activities through externally funded research projects, including financial support from the European Commission through the European Union budget, and is animated by the Programme Associates, leading scholars from different disciplines brought together by their interest in European integration and its future development.

For more information: http://europeangovernanceandpolitics.eui.eu/

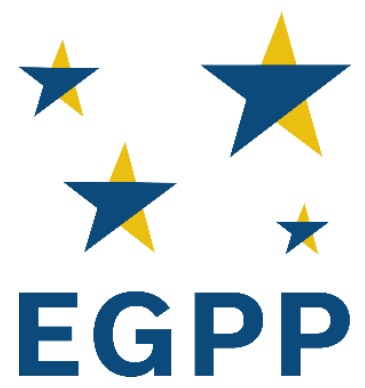





\begin{abstract}
The recent rise in the popularity of nationalist movements tells us that more attention should be paid to the effects of national feeling on politics. This article considers the potential relationship between national identity and active and allegiant citizenship and particularly whether nationalists and patriots are better citizens than those who have weaker feelings towards their country. We analyze these relationships using data from the European Values Study in 2008 and 2017. Our main models control for a variety of political, social, and economic causes of good citizenship and include country fixed effects in addition to three measures of national feeling. Our findings indicate that civic national identity is connected with better citizenship on virtually all of our outcomes, whereas ethnic national identity is frequently connected with worse citizenship. We explain these results using social identity theory and theories of prejudice. The results suggest that politicians ignore or downplay national feeling at their peril.
\end{abstract}

\title{
Keywords
}

Nationalism, citizenship, patriotism, political participation, civil society. 

You know, they have a word. It sort of became old-fashioned - it's called a nationalist. And I say, really, we're not supposed to use that word. You know what I am? I'm a nationalist, okay? I'm a nationalist. Use that word! Use that word!

Donald Trump

From the election of Donald Trump to Brexit to the success of parties like the National Front and the Alternativ für Deutschland, nationalism again appears to have captured political imaginations. Scholars tend to be fearful of these trends and indeed considerable literatures show connections between nationalism and conflict (O'Leary and Sambanis 2018) and between nationalism and intolerance towards outsiders (Kunovich 2009). Does this mean we should despair of a conflict-free future? Or does the resilience of national feeling despite predictions of its decline mean that nationalism provides certain goods that mostly cosmopolitan scholars are missing?

This paper considers one possible benefit of nationalism - that those with a strong national identity might be better citizens. While most research on nationalism has considered its impact on policy preferences, particularly policies related to trade, migration, and foreigners, we focus instead on less controversial and potentially positive effects on citizenship. We ask whether those who love their country more, to put the point too bluntly, also do more for their country. Do they participate more in politics? Do they help their communities more? Do they follow the rules more? One might expect love of country to inspire such sacrifices (Viroli 1995). Of course, such attachments could also point in the opposite direction if they lead to invidious comparisons and a perception that outsiders are free-riding on the nation.

Analyzing data from two waves $(2008,2017)$ of the European Values Study (EVS), we find that individuals who feel closer to their nation and more proud of their nation are more active and allegiant citizens who participate more in democratic processes and civil society and accept pro-social norms to a greater degree. These associations are large and consistent. They imply that national feeling can be useful.

However, that is not the end of the story. There is another nationalism, one based more on conceptions of ancestry, which is not so positive. This more exclusivist form of national identity, typically referred to as ethnic nationalism, also has persistent effects on citizenship, but the effect is consistently negative. Though we cannot say how to navigate between these two forms, i.e., what sort of patriotic education might best create good citizens, we can say that distinct forms of national feeling are important components of good and bad citizenship.

\section{Theory}

Nationalism, defined broadly as identification with one's country or ethnic group, is an indelible feature of the modern world. ${ }^{1}$ Yet, social scientists are divided about its effects on political behavior. In one view, national feeling is a social glue that holds societies together, leads members of a nation to sacrifice for each other, and undergirds the equality of citizens necessary for democracy (Miller 1995). Conversely, others see nationalism as a cause of exclusion, prejudice, and even violent conflict as those with strong national feelings discriminate against those who they perceive as outside of the nation, such as ethnic minorities, migrants, or foreigners (Gustavsson and Miller 2020).

These contrasting expectations are typically rooted in social identity theory as well as theories of prejudice. Tajfel's (1981) minimal group paradigm showed that individuals are easily induced to identify with a group and feel a sense of closeness that leads them to be proud of and work for their group. This paradigm would potentially explain the positive effects of national feeling. The question

1 We distinguish nationalism as an identity or feeling from nationalism as the ideology that the nation and state should be congruent. 
remains whether this positive feeling is inevitably counterbalanced with negative feelings or even hatred towards outsiders (Brewer 1999). Indeed, theories of prejudice are rooted in a similar psychological process (Allport 1954). While some see these positive and negative feelings as two sides of the same coin, there is also evidence that love for a group is separate from hatred towards other groups (see de Figueiredo and Elkins 2003 for a review).

Indeed, a standard finding in the literature on nationalism is that there are two distinct types of national feeling that do not necessarily correlate with each other (Jones and Smith 2001, de Figueiredo and Elkins 2003). One vision is typically referred to as patriotism or civic nationalism and its main characteristics are love of one's group, pride in one's country, and respect for the laws and institutions of one's country. ${ }^{2}$ A second type is referred to variously as nationalism tout court, ethnic nationalism, or credentialism. Its main features are the connection of the nation to birth and ancestry and feelings of superiority over other nations. ${ }^{3}$ The difference is sometimes characterized as a voluntarist identification in the case of civic nationalism and an ascriptive or objectivist identification in the case of ethnic nationalism.

Though nationalism has long been a subject of social science theorizing, its quantitative study is still relatively undeveloped (Kunovich 2009). Nevertheless, a number of studies have tested the consequences of national feeling. The main results indicate that nationalism and particularly ethnic nationalism often leads to negative feelings towards outsiders, whether foreigners, migrants, or minorities. At the same time, these effects are weaker or non-existent for these with higher levels of civic nationalism.

In one of the more systematic works, Kunovich (2009) found that ethnic nationalists favored more restrictive rules on naturalization, migration, and assimilation and preferred a foreign policy that emphasized national interests over collective security (de Figueiredo and Elkins 2003 had earlier shown that nationalists are more hostile to immigrants). Civic or multiple nationalists (those for whom both civic and ethnic identities are salient), by contrast, shared the preferences of other citizens. Huddy and Del Ponte (2020) meanwhile demonstrated that a similar form of ethnic nationalism was strongly and consistently related to opposition to globalization whether through protectionism or limits on migration. In the context of the EU, Muller-Peters (1998) and Carey (2002) showed that more nationalist Europeans were more opposed to the EU and the Euro. Lubbers and Coenders (2017) further found evidence that these attitudes had practical consequences as more nationalist attitudes were linked to voting for the anti-immigrant radical right in Europe.

A smaller number of studies have found more solidaristic effects of national feeling, typically civic national feeling. Thus, Huddy and Khatib (2007) showed that stronger national identity in the US was connected to higher voter turnout. Levendusky (2018) demonstrated with surveys and experiments that priming American identity through texts describing national achievements (a form of national pride) reduced affective polarization. Several studies have probed whether national feeling supports the welfare state based on the theory that nationalists would be more willing to support fellow citizens. In the most comprehensive study, Wright and Reeskens (2013) surprisingly found that only ethnic nationalism is associated with greater support for the welfare state and all forms of national feeling led to chauvinism against immigrants. There is some debate about whether these results apply to all societies as Johnston et al. (2010) show that civic nationalism is related to stronger support for the welfare state in Canada, but they connect this result with distinct historical circumstances.

Meanwhile, a substantial literature has probed the effect of nationalist feeling on tax compliance (for reviews see Geys and Konrad 2016 and Feldman and Slemrod 2006). Given that self-interested

2 Some scholars do not accept the concept of civic nationalism as a distinct type of nationalism. See Yack (2012) or Tamir (2019). Bonikowski (ND) argues that a four-fold scheme of liberal, ardent, disengaged, and restrictive nationalism better captures the different forms of national feeling, but operationalizing his schema is not possible with the data we have here.

3 The feeling of superiority is not exclusive to ethnic nationalism and could be associated with civic nationalism. 
individuals would prefer not to pay taxes, other motivations might help to promote compliance. Several studies have thus demonstrated that countries with higher levels of patriotism collect more tax revenues and have a smaller shadow economy. This applies to a greater extent in wartime, though it also appears in peacetime, and finds support in qualitative studies of the use of nationalist propaganda to promote tax compliance.

The main gap that we identified in the literature is in the effect of national feeling on citizenship. Most studies have focused on policy preferences and particularly preferences on policies related to outsiders or foreigners. These preferences are, of course, contested. Citizens may legitimately hold different opinions on the proper amount of globalization or the proper number of migrants.

We take a step back by trying to link national feeling with less controversial measures of good citizenship that are arguably essential to a functioning democracy. Those who have studied these connections before have either focused on a single country, typically the US, or a limited set of outcomes, usually voting or tax compliance, rather than general measures of good citizenship in multiple countries. Our paper attempts to fill this gap by looking at the association between national feeling and multiple characteristics of good citizenship across a large group of countries.

\section{Hypotheses}

This paper analyzes whether national feeling and different subtypes of national feeling are associated with better citizenship, in particular active and allegiant citizenship. We conceptualize active and allegiant citizenship as consisting of three parts that roughly correspond to the theories of Almond and Verba (1963) and Putnam et al. (1994). This is not a complete characterization of good citizens and is partially driven by data availability, but it does encompass some major parts of what is commonly perceived to be good citizenship (for example, Van Deth et al. 2017).

In the first place, we are interested in the participatory aspect of citizenship as theorized by Almond and Verba (1963). Good citizens should be active participants in democratic politics and supporters of democracy. Participation depends on support for democracy and the political system. In turn, informed participation ensures that the interests of all citizens are represented in politics. In practical terms, this means voting, following politics, recognizing the importance of democracy, and being satisfied with the political system.

Second, good citizens work to make their communities better. This means being a part of civil society by joining voluntary organizations, doing volunteer work, and trusting others. These actions are wellknown as key elements of Putnam et al.'s (1994) conception of civic community. He argues that civic community both has positive internal effects on citizens and makes democracies more responsive and efficient.

Third, good citizens should behave in prosocial ways by following the rules and not taking advantage of others. They should pay their taxes and fares on public transport and not accept bribes or benefits to which they are not entitled. These elements come close to Almond and Verba's (1963) conception of allegiant citizenship, where citizens follow and obey the law. ${ }^{4}$

Why should national feeling affect these aspects of citizenship? The basic idea in J.S. Mill's (2010) rendering is that national feeling means that people are "united amongst themselves by common sympathies... which make them co-operate with each other more willingly than with other people, desire to be under the same government, and desire that it should be government by themselves or a portion of themselves exclusively." Common national feeling should lead individuals to see co-nationals as equal citizens and thus democracy as the proper form of government for them. It should further lead them to be willing to make sacrifices that would enable this democracy to work better such as voting, volunteer

4 Almond and Verba's (1963) overall conception of a civic culture combines participatory and allegiant orientations. 
work, and paying their taxes. These connections build on Terry and Hogg's (1996) finding that those who identify more strongly with a group are more likely to conform to group norms. Liberal nationalists like Miller (1995) make exactly this case for nationalism - it is the glue that allows trust and solidarity among diverse groups.

A similar picture emerges from a more historical literature on the origins of nationalism and its effects. Most famously, Weber (1976) describes how peasants were turned into Frenchmen and citizens at the same time. Rustow (1970) argues that this sort of family feeling is a prerequisite for democracy as such. Darden and Grzymala-Busse (2006) meanwhile show evidence that early development of such national feeling made citizens in communist countries better able to resist rule by the Soviet Union.

However, as the literature on ethnic nationalism shows, nationalism may not always work in this way. Insofar as individuals see the nation in exclusivist or ethnic terms and believe that others living within the country are not fully members, they may act in less community-oriented ways. Here the mechanism relies on reactions to cheating. If others are are benefitting from the nation while not properly being part of it, then one should not continue providing these benefits. In this situation, being a good citizen - that is, sacrificing to benefit one's community - means being duped or taken advantage of by those who are not sacrificing. One might then "free ride" by not participating and by not following the rules. Only a more all-encompassing form of nationalism should have positive effects posited by Mill.

An objection is that ethnic nationalists might react to this situation by engaging in forms of active and allegiant citizenship based around their in-group. Putnam (2007), however, found an overall decline in civicness in heterogeneous communities (more generally Dinesen et al. 2020). He argues that citizens instead "hunker down" rather than contribute to public goods. Similarly, citizens with ethnic nationalist beliefs might have less faith in democracy as a system of government precisely because it treats all citizens equally, even those not properly part of the nation. These considerations lead to our two main hypotheses.

H1: Stronger feelings of pride and closeness to one's country (in short, civic national identity) are positively associated with active and allegiant citizenship.

$\mathrm{H} 2$ : Stronger feelings of ethnic national identity are negatively associated with active and allegiant citizenship.

Country-level factors may further affect the relationship between nationalism and citizenship. ${ }^{5}$ For a number of reasons, we expected a different relationship in Western and postcommunist Europe, each of which comprises about half of the European Values Study, our main source of data. In the first place, Pop-Eleches and Tucker (2017) have demonstrated that there are large attitudinal differences between individuals who grew up in a communist regime and those who did not. One of the most relevant effects is their finding of greater skepticism about democracy among citizens who experienced communism first-hand. Similarly, differences have been found for civil society and electoral turnout, other key dependent variables, where for a variety of reasons postcommunist countries lag behind the industrialized democracies (Howard 2003, Kostelka 2017). Adding to the differences is the mediocre democratic performance in many of these countries.

Possibly more important are different experiences with nationalism. In contrast to postwar Western European countries, communist regimes tended not to come to terms with the nationalist feelings that had been at the root of fascism in the interwar and war years (Subotic 2019). Indeed, there has long been a presumption that Eastern Europe is a region of ethnic nationalism compared to civic nationalism in Western Europe (originally Kohn 1944, see Janmaat 2006 for confirmation and Shulman 2002 for doubts). Moreover, the fall of communism was motivated by and associated with national liberation

5 We also considered other country-level factors that might affect this relationship. In particular, we hypothesized that countries with larger migration flows and a greater percentage of foreign-born population had a different relationship. We did not find any significant relationships when running multilevel models with these variables. 
(Beissinger 2002, Bunce 1999). As Milanovic (2017) points out, many of these countries became both ethnically homogeneous and independent states for the first time in their history and this was a matter of more importance to citizens than democratization. For these reasons, we might expect nationalism to be related to citizenship in different ways in postcommunist Europe. In particular, ethnic nationalism might not have the same negative association with citizenship in the postcommunist region as it does in Western Europe.

H3: The relationship between ethnic national identity and active and allegiant citizenship is reversed in postcommunist Europe.

\section{Data and Methods}

To test these hypotheses, we used data from the fourth and fifth waves of the European Values Study (EVS) conducted in 2008-2010 and 2017-2020 (EVS 2011, EVS 2020). We chose the EVS because it includes a range of measures of national feeling along with a range of measures of good citizenship for a large group of countries. While some studies include more nuanced measures of nationalism (particularly, the International Social Survey Project modules on nationalism), they do not include the outcomes we are interested in. Conversely, other studies with a wider range of outcome measures (for example, the World Values Survey) do not include good measures of alternative forms of national feeling. The EVS covered 30 countries in the fifth wave and 44 countries in the fourth wave. Each wave is about evenly divided between Western Europe and the postcommunist region. A list of countries is included in the appendix (Tables A5 and A6).

The wording of the survey questions we used and descriptive statistics are in the appendix (Tables A1-A4). The key independent variables in our analyses were three measures of national feeling. We measured ethnic nationalism with answers to the question of whether "in order to be fully [COUNTRY NATIONALITY] you need to have [COUNTRY'S] ancestry." By contrast, our measures of civic nationalism asked "how proud are you of [COUNTRY]" and "how close do you feel to [COUNTRY]". Unfortunately the closeness question was not asked in the 2008 wave. Similar questions have been used to capture civic and ethnic nationalism in previous works and the distinction has been confirmed in numerous factor analyses (Johnson and Smith 2001, de Figueiredo and Elkins 2003, Kunovich 2009). ${ }^{6}$ Each of these variables is measured on a four-point Likert scale. Country averages for all three variables are in the appendix (Figures A1 and A3).

Our main dependent variables can be divided into three groups. The first group captures the participatory element of democratic citizenship. Good democratic citizens should vote in elections (for the fifth wave we summed two questions on voting in past national and local elections to produce a 6point scale, while for the fourth wave we used a dichotomous question about intention to vote in the next national election) and follow politics (for the fifth wave a 20-point scale based on a sum of 5-point scales for following politics on TV, radio, newspapers, and social media and for the fourth wave a single 5-point scale for following politics on TV, radio or newspapers). We add to these basic requirements a belief in the importance of democracy and satisfaction with the current political system as such beliefs may help to maintain a democratic system (for the fifth wave, both were measured by a 10-point scale; for the fourth wave, both were measured on a 4-point scale and the democracy question referred to democracy being better than other forms of government and the satisfaction question mentioned satisfaction explicitly with democracy).

6 Pride and closeness are commonly used to measure civic national feeling (for example, Huddy and Khatib 2007, Huddy and del Ponte 2020). While ancestry is similarly frequently used as part of a conception of ethnic national feeling, most studies use ISSP data which includes additional measures of this construct (Kunovich 2009, de Figueiredo and Elkins 2003, Huddy and del Ponte 2020). Lubbers and Coenders (2017) use nearly identical measures to our own. 
The second aspect of democratic citizenship is variously called civil society or civic community. We measured this as membership in voluntary organizations (a sum of the number of memberships in 9 different organizations for the fifth wave and 15 organizations for the fourth wave), voluntary work (a dichotomous variable on whether the respondent had done volunteer work in the last six months), and trust in others (a dichotomous variable indicating whether most people can be trusted or not). ${ }^{7}$

The third set of outcomes encompasses the willingness of citizens to follow the rules of the social order and not take advantage of others. We operationalize these as beliefs on the justifiability of cheating on taxes, accepting a bribe, avoiding a fare on public transport, and receiving benefits that one is not entitled to. Each is measured on a ten-point scale though the means tend to be quite high.

We considered producing summary measures for each of these three aspects of good citizenship. However, calculations of Cronbach's alpha indicated that the measures of active citizenship and civic community were only weakly related $(\alpha=\sim 0.4)$. Only the measures of rule following had a stronger relationship ( $\alpha=\sim 0.7$ ). For this reason, we primarily present results for the individual elements separately.

We would add that these three aspects do not capture the entirety of good citizenship. We chose them because they constitute beliefs and actions that are relatively uncontroversially regarded as behaviors of good citizens. They thus differ from the sort of contested policy preferences that are commonly investigated in studies of national feeling. Our choices were further guided by the availability of measures for these aspects in recent waves of the EVS.

For each of these outcome variables, we ran regressions that included all three measures of national feeling. ${ }^{8}$ These were OLS, logit or ordinal logistic regressions depending on the nature of the dependent variable. We also included country fixed effects to capture unobserved heterogeneities across countries.

We further included controls for many of the social and demographic factors that might influence both national feeling and good citizenship. These include age, a quadratic term for age, university education, sex, income, unemployment, church attendance, and left-right self-placement. ${ }^{9}$

The analyses presented below exclude respondents who might not fit ancestry definitions of the nation because we expected national feeling, particularly the ethnic nationalism variable, to work very differently for them. This included those who fulfilled at least one of the following criteria: (i) they were not born in the country; (ii) they had at least one parent not born in the country; (iii) they did not have the country's nationality. In the 2008-2010 sample information on parents was missing. Thus, only respondents who were born in country and had the country's nationality were included. The inclusion of these respondents did not change the results for the main independent variables and when included the coefficients on the outsider variable were strongly negative - that is, they were less likely to vote and participate and they were more likely to think that not following the rules was justifiable.

\section{Results}

For each of our sets of dependent variables, we present figures showing the estimated coefficient and confidence intervals for our three main independent variables - one measure of ethnic national identity (belief that ancestry is necessary to be a member of the nation) and two measures of civic national identity (closeness to their country and pride in being a citizen of their country). The dependent variables

7 The voluntary work variable was not available for the fourth wave.

8 Despite their similarities, the correlations between the three variables were relatively low. For the fifth wave, the correlation coefficient for ethnic nationalism and closeness was 0.05 , for ethnic nationalism and pride 0.22 , and for closeness and pride 0.33. For the fourth wave, ethnic nationalism and pride were correlated at 0.21 ,

Urban/rural variables were missing for some countries and therefore were not included. Their inclusion for the countries where they were available did not change the results. 
have all been recoded so that positive coefficients mean that greater national feeling is associated with better citizenship as we have defined it above. All of these estimates include the controls mentioned above along with country fixed effects. The coefficients and standard errors for the full models are included in the online appendix (Tables A7-A28).

We begin by analyzing responses from the fifth wave of the European Values Survey conducted between 2017 and 2020 (EVS 2020). Figure 1 presents results for four measures related to support for democracy and participation in democratic politics. They are the importance of democracy, satisfaction with the political system, following politics, and voting in elections. For the full sample, we found the predicted result for each question. Greater closeness to one's country and pride in one's country are positively and statistically significantly associated with more support for and participation in democracy, while greater ethnic nationalism is negatively and statistically significantly associated with the same outcomes. 


\section{Figure 1: Participation, Democracy, and Nationalism, 2017}
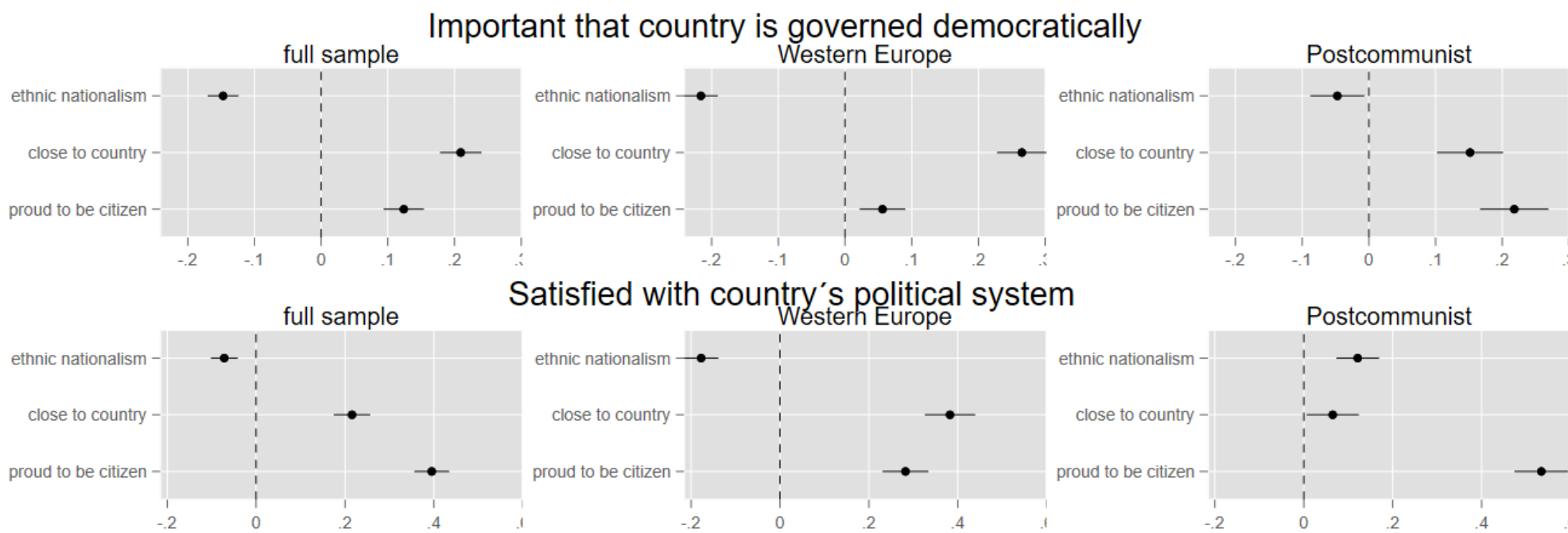

Satisfied with country's political system
Westerh Europe
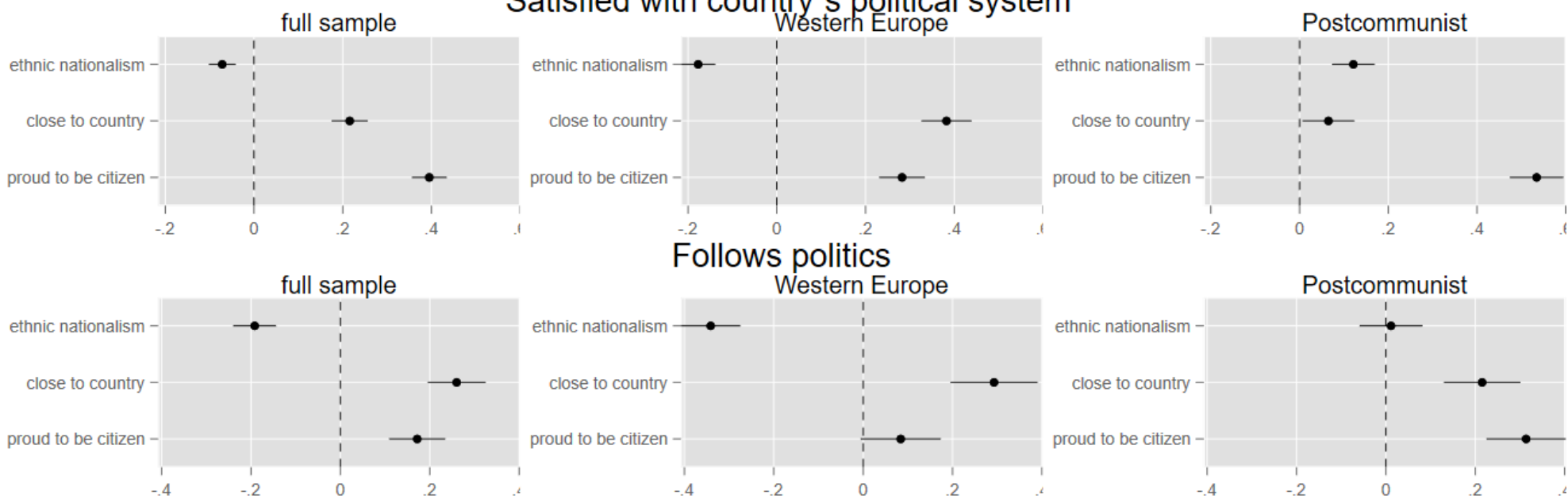

Follows politics
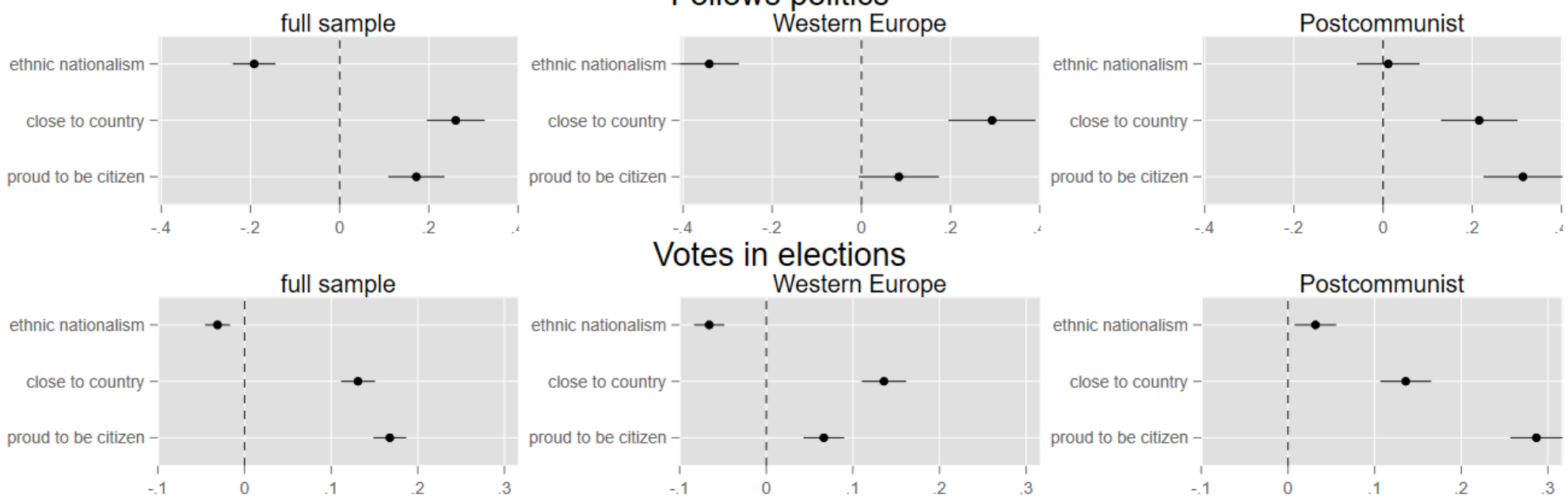
Turning to the Western Europe sample, we see that it mirrors the sample as a whole. Here the association is stronger for closeness to one's country than for pride (though both have statistically significant associations) and the negative association with ethnic nationalism is larger. The postcommunist sample, however, diverges somewhat. Ethnic nationalism in the region has a less negative and sometimes even positive association with the main outcomes, particularly satisfaction with the political system and voting. And unlike Western Europe, it is pride rather than closeness which has stronger associations. These results support scholars who see a stronger ethnic component to nationalism in postcommunist Europe. Indeed, pride could also be considered more similar to the ethnic conception than closeness.

Figure 2 presents results for three dependent variables connected to what Putnam calls civic community. They are membership in civil society organizations, voluntary work, and generalized trust in others. For the full sample, closeness is powerfully related to all three forms of community and ethnic nationalism is negatively related to all three. Pride, however, is somewhat anomalous as it has a smaller and slightly negative association with the three measures of civic community. National pride might be somewhat orthogonal to these behaviors and attitudes which are less political than the others we consider. 
Figure 2: Civic Community and Nationalism, 2017
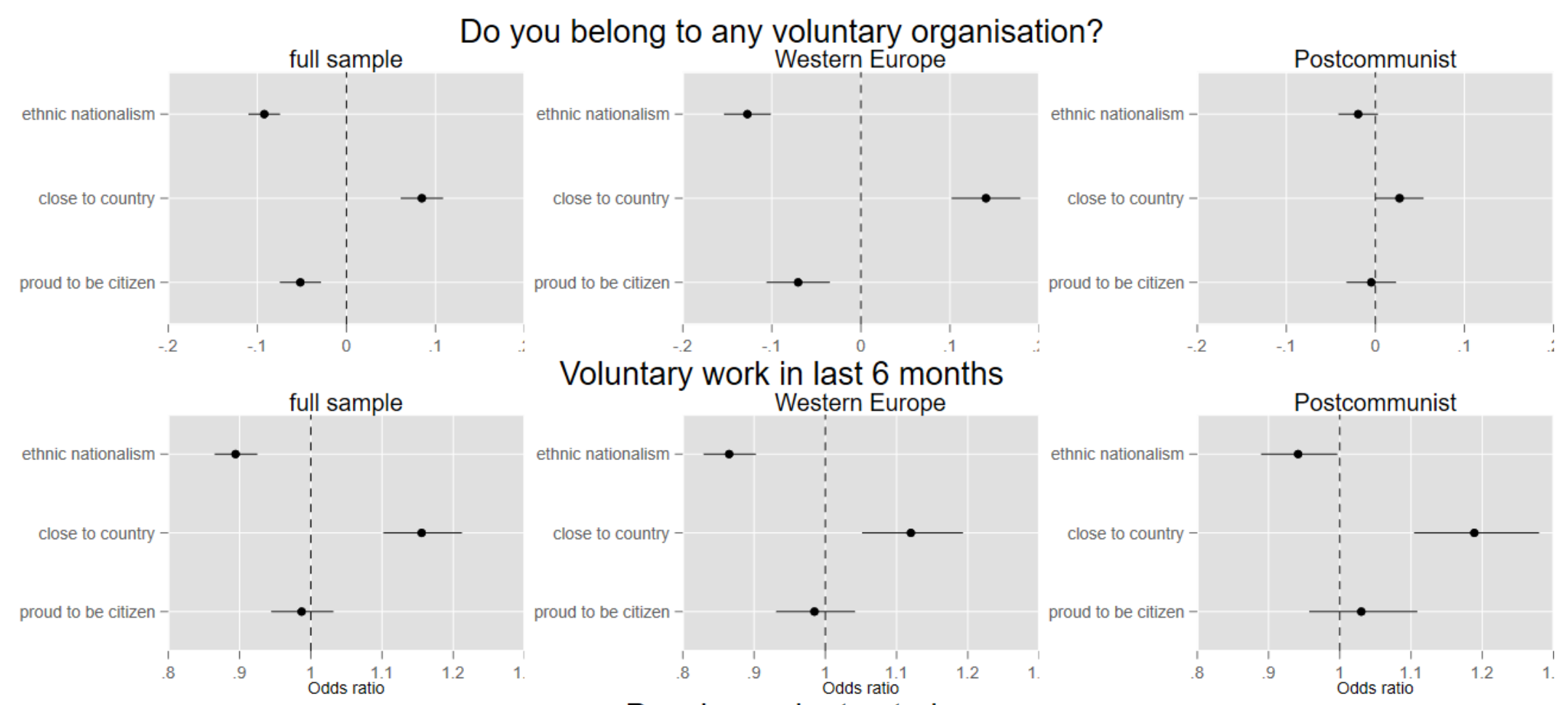

\section{Voluntary work in last 6 months}
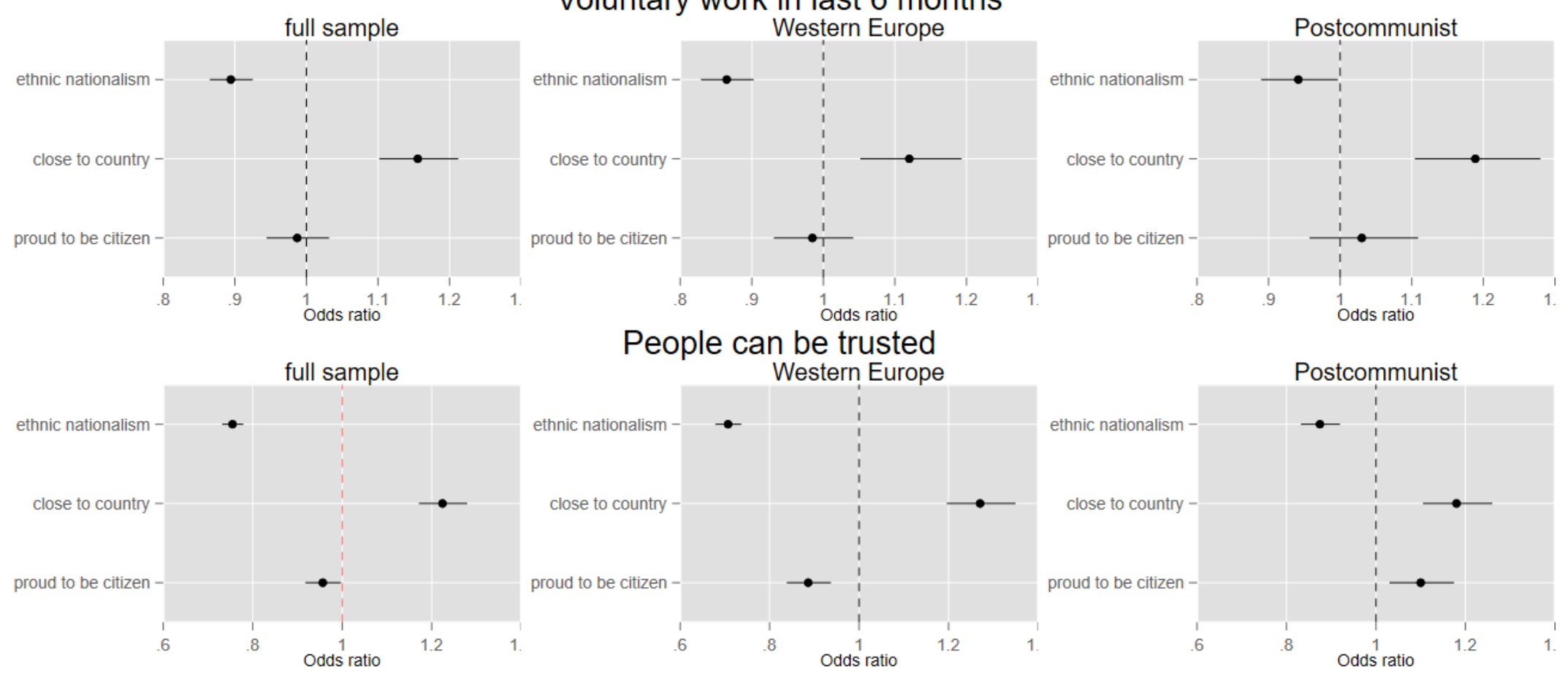
The differences between Western Europe and the postcommunist countries are even more apparent for civic community. While Western Europe looks similar to the full sample, the postcommunist results differ substantially. Though the variables maintain the same ordering, the coefficients tend to be much smaller and less significant, especially for the voluntary organizations and volunteerism variables. This corresponds with work by Howard (2003) who argues that the weakness of civil society is a defining characteristic of the postcommunist region. He attributes this to the legacies of mandatory participation and vibrant private networks under communism as well as disappointments with transition. Nationalist feelings thus do not translate into more joining or volunteering in the region as they do in Western Europe.

Figure 3 turns to the pro-social preferences of following the rules by not cheating on taxes, not accepting bribes, paying one's fare on public transportation, and only claiming state benefits that one is entitled to. The full sample results again confirm our main hypotheses with one exception. Closeness and pride are positively and statistically significantly associated with following the rules in all of these ways, while ethnic nationalism has a negative association for three of them. The exception is avoiding a fare on public transportation where ethnic nationalism has a positive relationship so that those with higher ethnic nationalist feelings are more likely to believe that skipping fares is wrong. A possible explanation is that paying or not paying one's fare is less associated with outsiders (foreigners, minorities) than the other actions here. It could be seen as more a spur-of-the-moment and low-stakes decision. The other actions, by contrast, are easier to see as a systematic defrauding of the government. 
Figure 3: Prosocial Attitudes, 2017

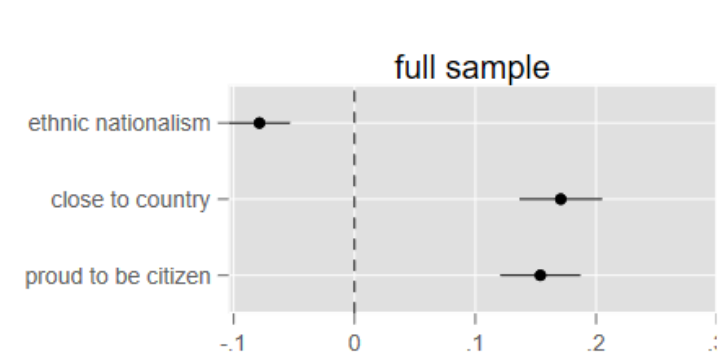

\section{Cheating on taxes never justified}
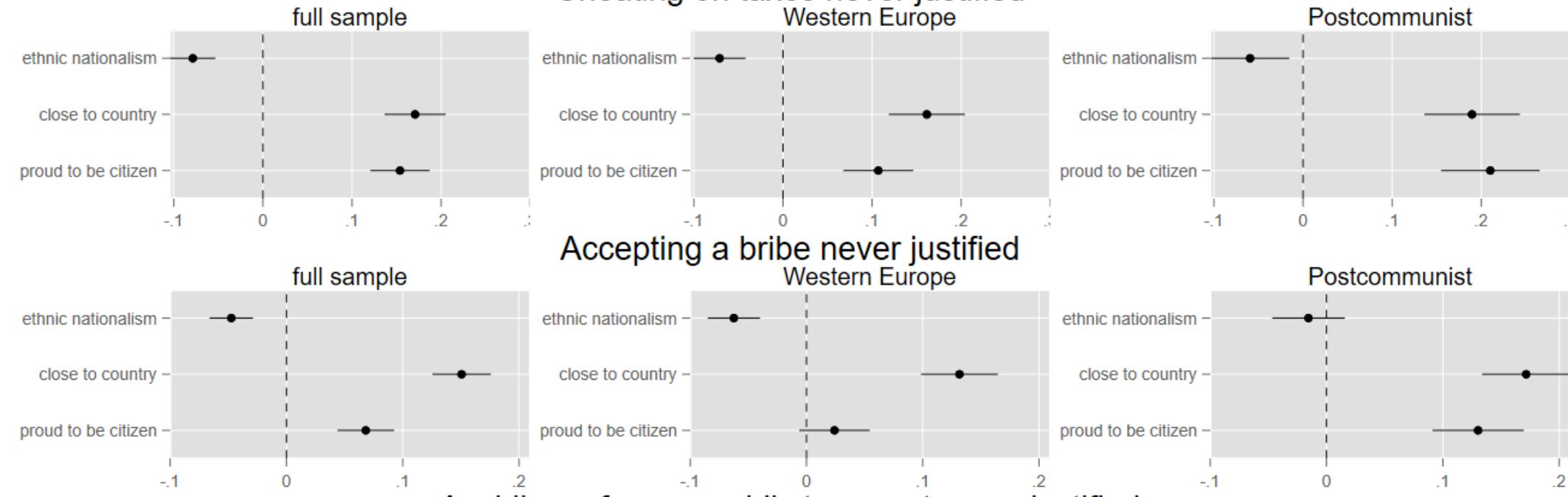

\section{Accepting a bribe never justified}
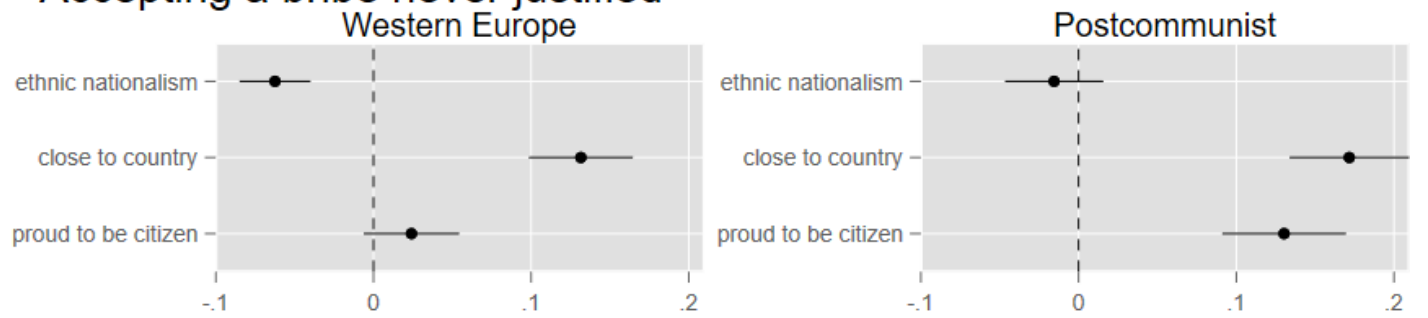

Avoiding a fare on public transport never justified
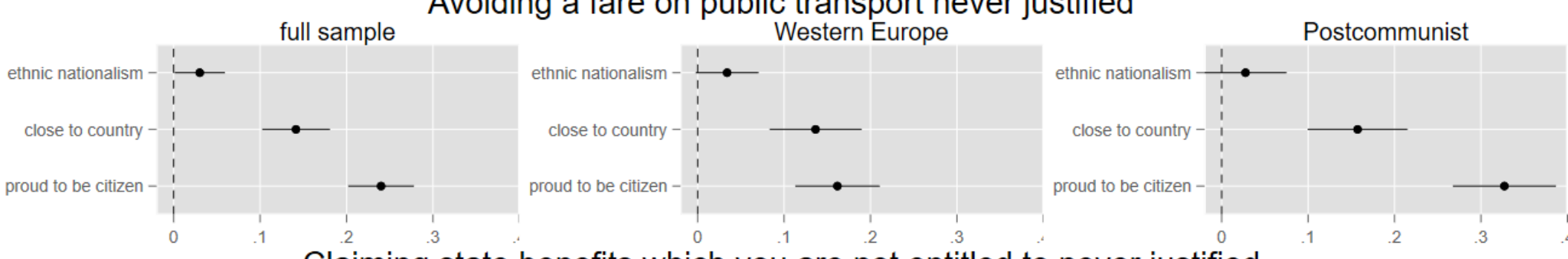

Claiming state benefits which you are not entitled to never justified
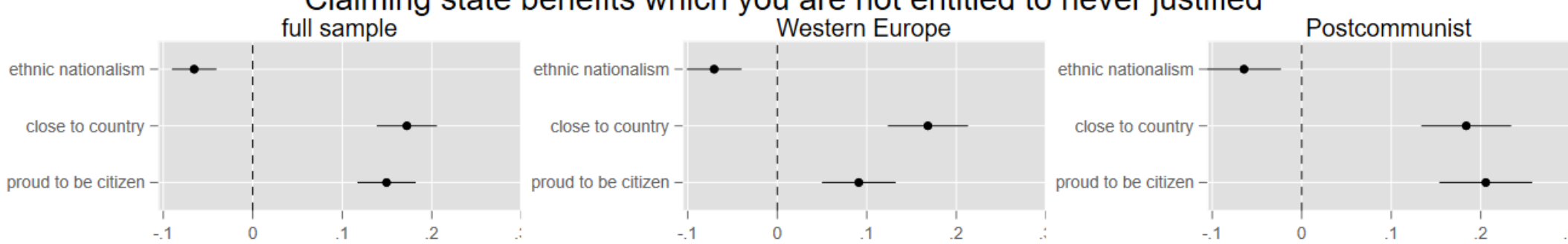
The differences between Western Europe and postcommunist countries are less apparent for rulefollowing than they were for our first two sets of results. Mirroring the results on democracy, closeness is slightly more associated with good citizenship in Western Europe than in postcommunist countries, where pride instead tends to have a stronger association. Similarly, ethnic nationalism appears to have slightly less of a negative association (particularly for accepting a bribe) in the postcommunist region. But overall, the results for the two regions are mostly similar.

We also considered one final dependent variable that we had difficulty characterizing. It is willingness to fight for one's country. While in some ways this desire is paradigmatic of nationalism (Kateb 2006), it is also difficult to say that pacifists or those who oppose fighting for other reasons are not good citizens. We did expect this variable to behave differently than the others and perhaps be positively connected to ethnic nationalism. In fact, we found that pride and closeness are both positively and statistically significantly associated with willingness to fight for one's country, pride more than closeness, but that ethnic nationalism had a near zero relationship. These results appeared in all three samples. Willingness to fight thus behaves much like our other dependent variables.

To check how robust these results are, we conducted similar analyses for the fourth wave of the European Values Study conducted from 2008 to 2010 (EVS 2011). This study, however, lacked a measure for closeness and so we were only able to include the measures of ethnic nationalism and pride. Several of the dependent variables were also slightly different in their wording or coding (see Tables $\mathrm{A} 1$ and $\mathrm{A} 3$ in the appendix).

Figure 4 presents the results for our four measures of democratic participation. All of these variables took slightly different forms than the 2017 survey, which provides another robustness test. The support for democracy variable mentioned that democracy may have problems but is better and the satisfaction variable explicitly mentions democracy rather than the political system. Following the news and voting were both dichotomous variables in the 2008 sample instead of continuous variables as they were in the 2017 sample.

For the full sample and for Western Europe, we see our standard result of positive associations with national pride and negative associations with ethnic nationalism, though the size of the ethnic nationalism coefficient was sometimes relatively small, especially for satisfaction with the way democracy develops. The postcommunist sample differed in that ethnic nationalism did not have the expected negative associations. In all four cases, the estimated coefficient was quite close to zero and for following politics, it was slightly positive. 
Figure 4: Participation, Democracy and Nationalism, 2008
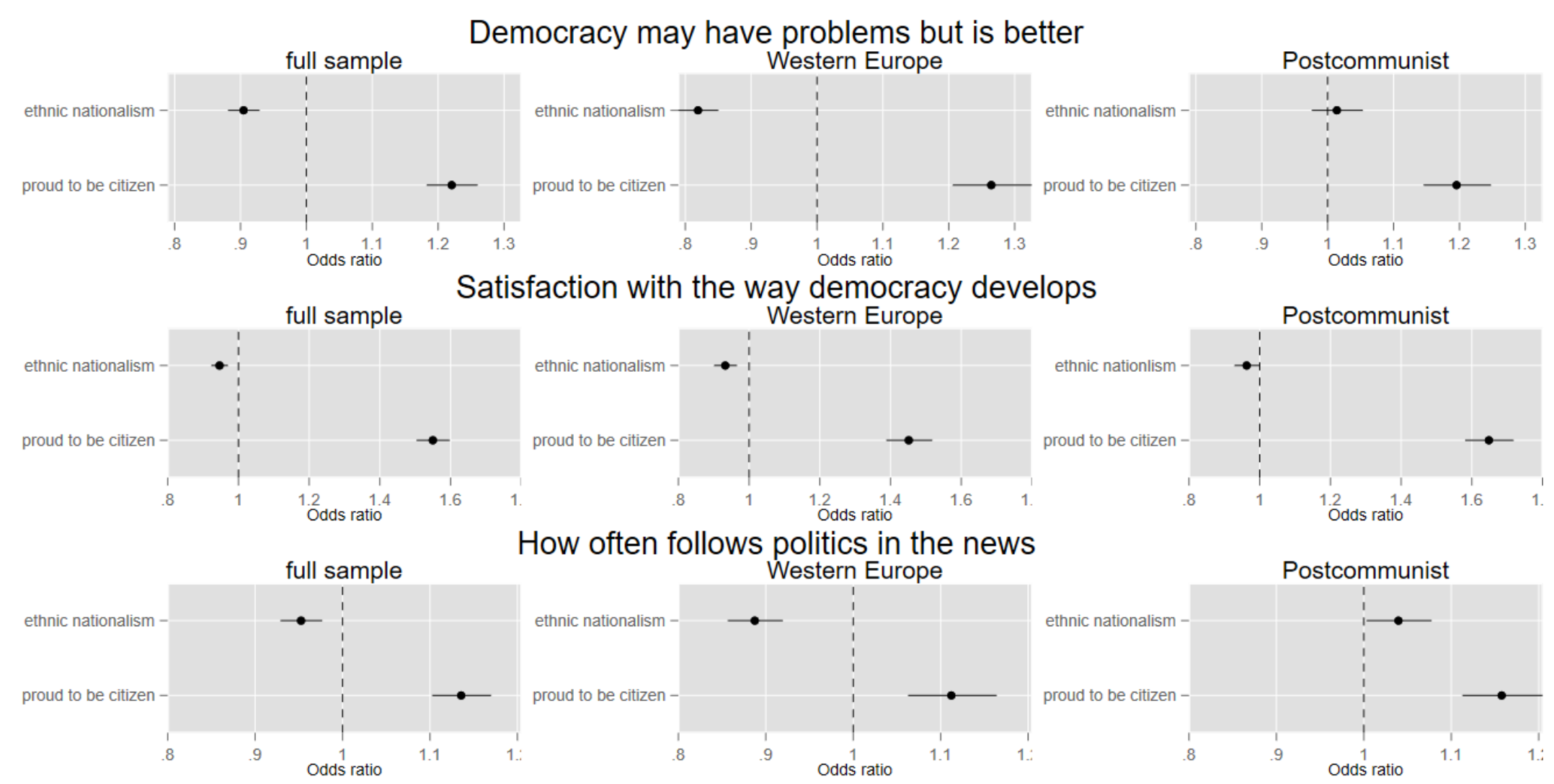

How often follows politics in the news
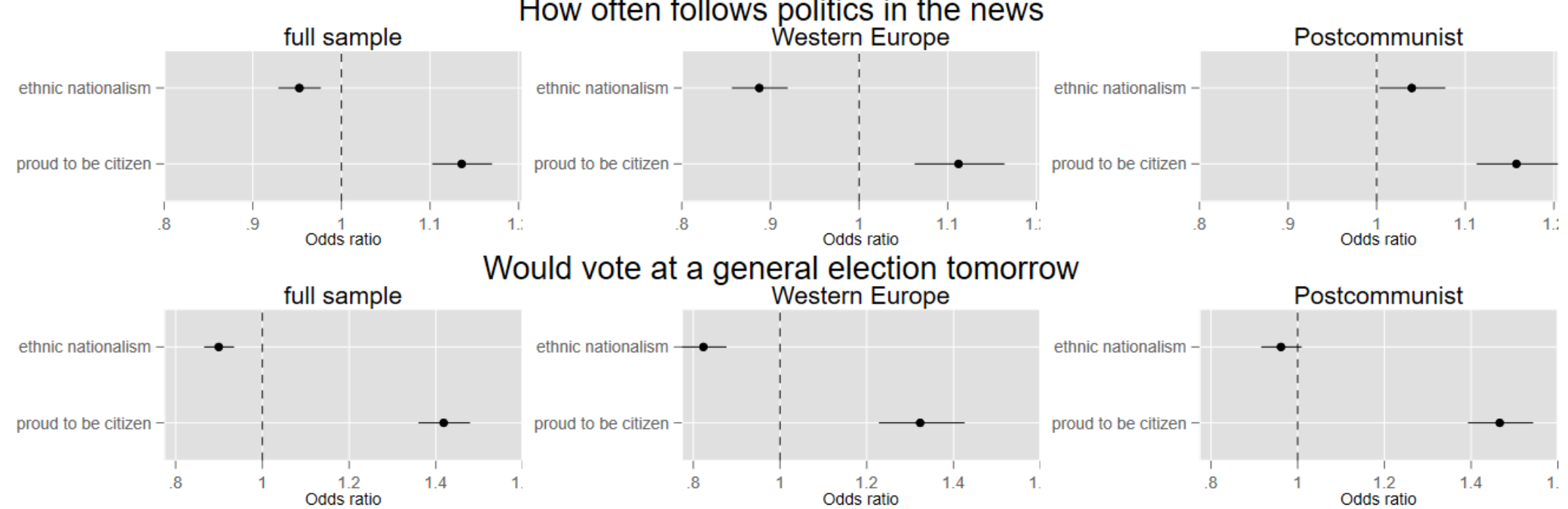

Would vote at a general election tomorrow
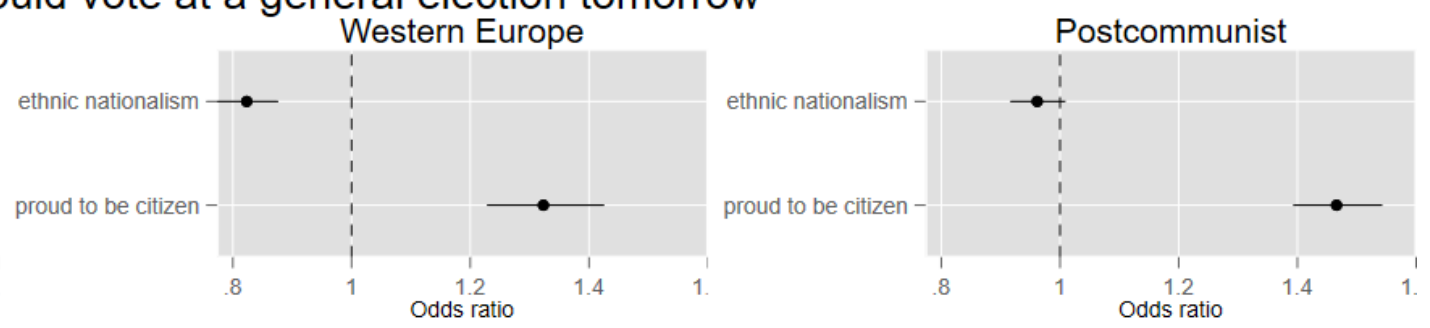
Are Nationalists Better Citizens?

Figure 5: Civic Community and Nationalism, 2008

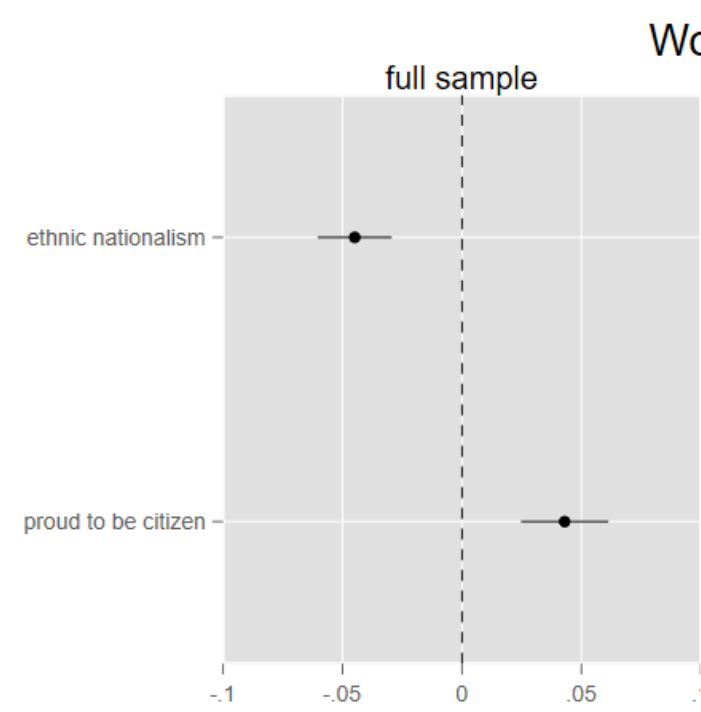

Works unpaid for a voluntary organisation
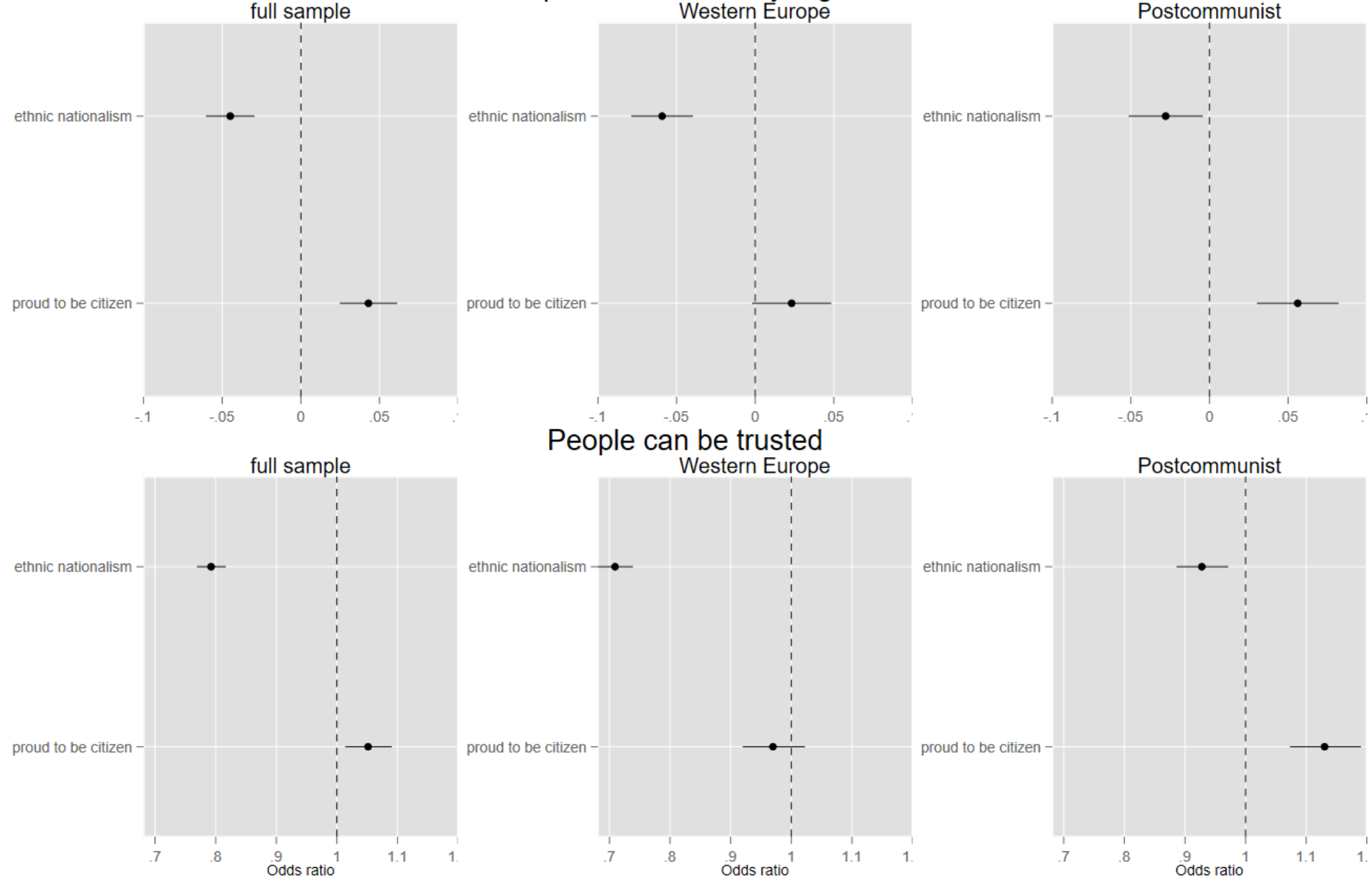
Figure 5 presents results for civic community. While the results for the full sample show the expected positive association for pride and the negative association for ethnic nationalism, the regional subsamples behaved somewhat differently. In Western Europe, national pride was not very associated with working for a voluntary organization or trusting others. Pride does not seem to capture the positive sort of national feeling that closeness did in the 2017 data. Pride does have more of this role in the postcommunist region, while ethnic nationalism does not have quite such a negative association.

Finally, Figure 6 shows results for prosocial preferences. The strongest result is the consistently positive association between national pride and beliefs that anti-social behavior is unjustified. These results are statistically significant for all three samples and are even larger for the postcommunist region than for Western Europe. Ethnic nationalism, however, has relatively low associations with these attitudes. In the full sample, it is a precisely estimated zero for cheating on taxes and accepting a bribe, slightly negative for claiming unearned state benefits, and significantly positive for avoiding fares. This last case corresponds with the mixed results from the 2017 survey. Ethnic nationalism also behaves differently between Western and postcommunist Europe. In Western Europe, the associations are mainly negative (except for avoiding fares) and in postcommunist Europe they are mostly positive, though not substantively large.

Overall, the 2008 sample confirms most of our findings from the 2017 survey. Again, national pride tended to have positive associations with good citizenship, while ethnic nationalism tended to have negative associations. As in the previous analysis, pride seemed to be a stronger predictor in postcommunist Europe than in Western Europe. The more positive form of national feeling for Western Europe - closeness to one's country - was missing from this survey. Further, ethnic nationalism had less negative associations in these surveys, especially for postcommunist Europe. Though we are hesitant to make generalizations about changes over time due to differences in question wording, postcommunist countries were more distinct in the survey conducted a decade earlier which could mean that attitudes in the region are shifting towards those common in Western Europe or alternatively that Western Europe is shifting towards postcommunist norms.

We conducted a number of other robustness tests. We ran models with additive and factor-analytical combinations of our three classes of dependent variables (despite low Cronbach's alphas as noted above). We also constructed multilevel models while controlling for the type of region (Western versus Postcommunist) at the macro-level. In each case, the results are substantively equivalent to those presented here. 
Figure 6: Prosocial Attitudes and Nationalism, 2008

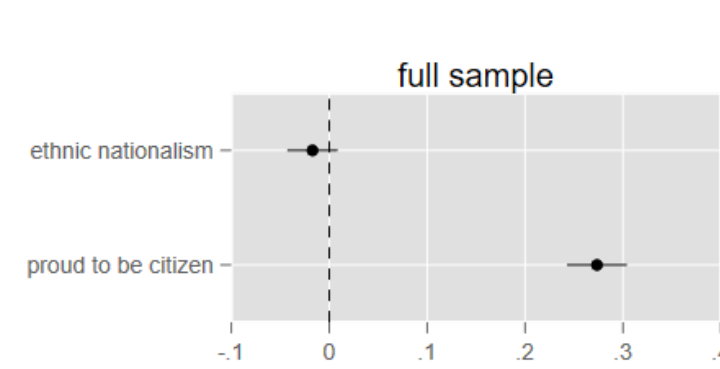

\section{Cheating on taxes never justified}
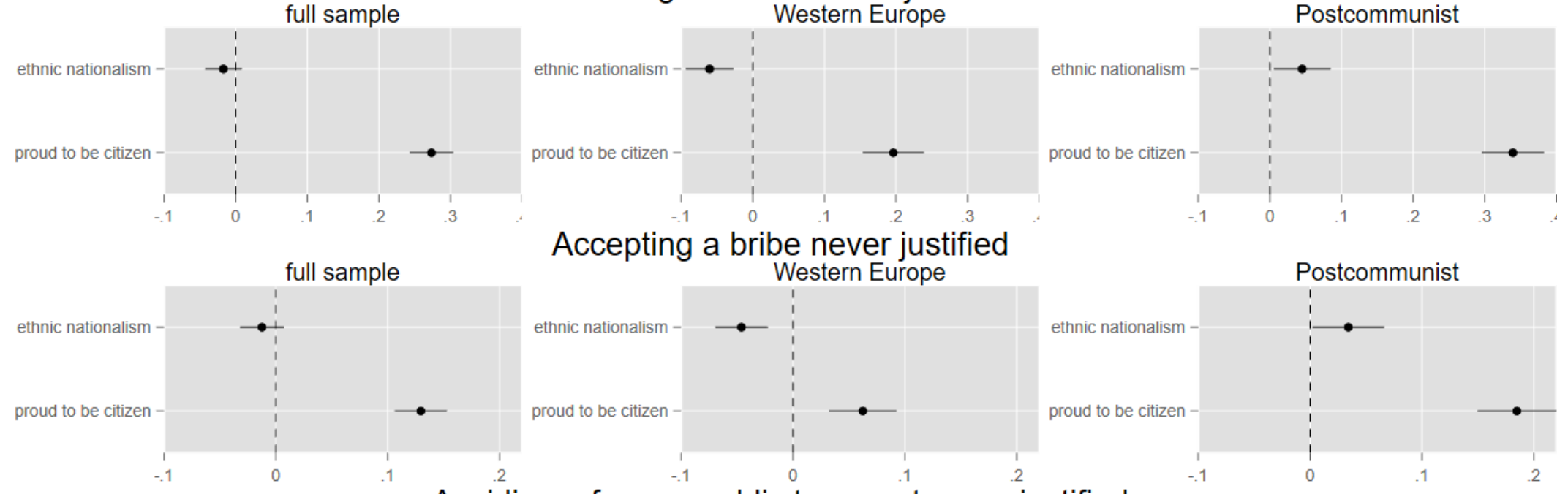

Accepting a bribe never justified
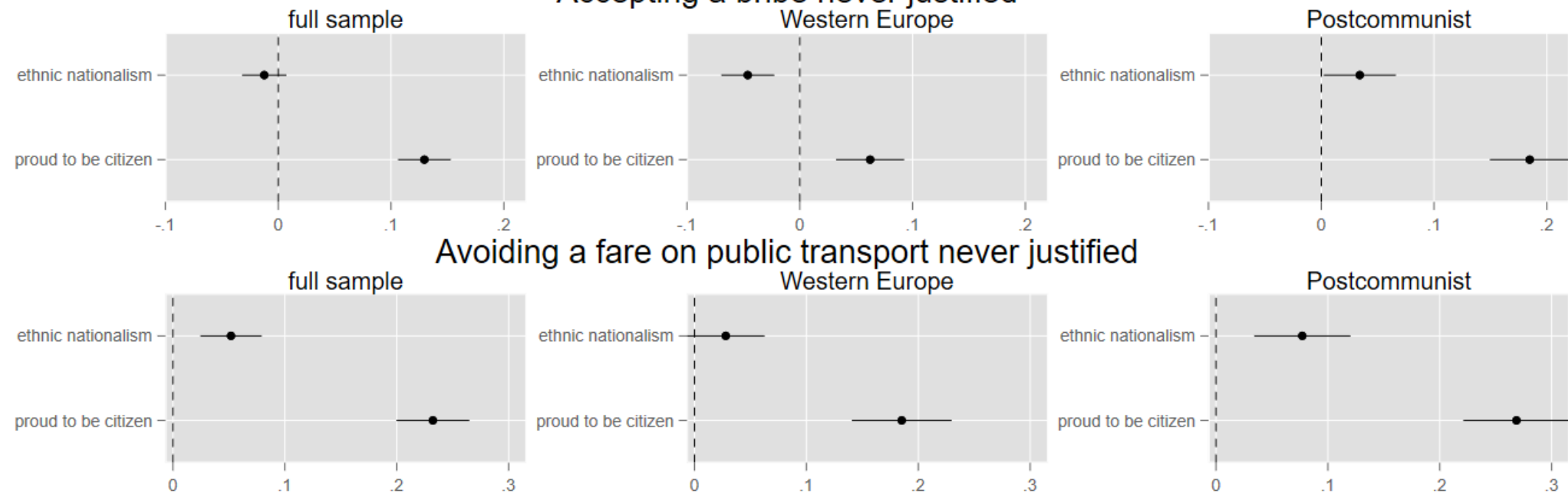

Claiming state benefits which you are not entitled to never justified

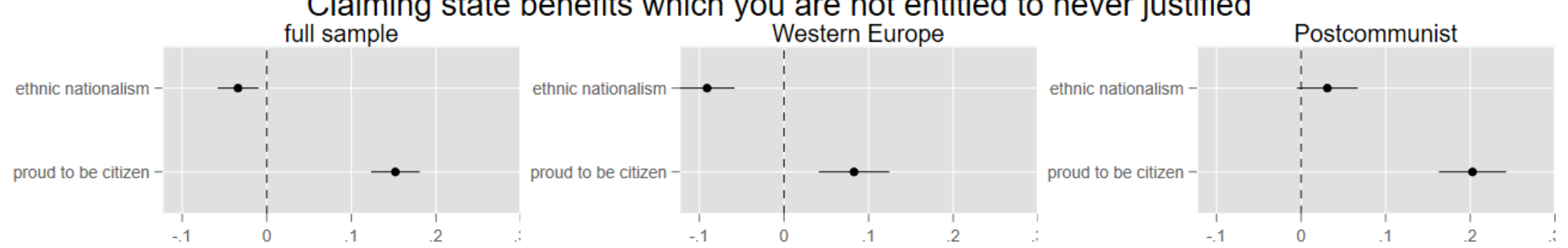




\section{Conclusion}

Our analysis of European survey data has shown that there is a strong, positive, and consistent association between pride in or closeness to one's country and a range of measures of active and allegiant citizenship. Citizens who are proud of their country or feel close to it are more likely to believe in democracy, participate in and follow politics, engage in volunteerism or voluntary organizations, trust others, and dislike cheating the government in a variety of ways. Conversely, those who embrace an ethnic national identity - a belief that only those with the country's ancestry should be citizens - are less likely to act in most of these ways. In short, what is commonly characterized as civic nationalism appears to be related to good citizenship and ethnic nationalism to bad citizenship.

There are, of course, nuances in these findings. Many of the associations were stronger in Western Europe than in postcommunist Europe. In Western Europe, it was closeness to one's country that seemed to have a stronger effect, while in postcommunist Europe it was pride in one's country. Further, ethnic national feeling was sometimes a neutral or less negative force in postcommunist Europe, though it rarely had large and positive effects.

We would emphasize that these results should not be given a causal interpretation. Although we controlled for a variety of correlates of good citizenship as well as country fixed effects and we found that the associations held up over time, national feeling is far from exogenous and without experimental or natural experimental manipulations, we cannot say that increasing or decreasing particular forms of nationalism would affect different aspects of citizenship. While we have theorized reasons why the two forms of nationalism might have these effects, we have neither tested these mechanisms nor accounted for the origins of national feeling.

Our main results correspond with a recent wave of normative theorizing on the benefits of national identity. Cowen (2019), for example, suggests that we recognize a doctrine of practical nationalism. Practical nationalism means a recognition that a system of nation-states has worked relatively well and that most citizens feel an attachment to them. However, some nationalists are racists or bigots and it would be good to weaken those forms. In his view, "The best way for that to happen is to let practical nationalism reign, while at the margin seeking to soften it with moral cosmopolitanism... Each perspective, standing on its own, is intellectually vulnerable, yet the two outlooks together are not quite fully harmonious. It is this dynamic clash, however, that helps to account for the strength of each."

An open question is how exactly to increase the proper kind of nationalism and reduce the wrong kind. The creation of national feeling was typically accompanied by coercive means and the forced assimilation of minorities (Weber 1976). Such means are no longer acceptable. The use of schools and civic rituals to promote pride and closeness would be the solution that most readily leaps to mind, but it is also one that already exists in just about every country. Indeed, at least in Europe, levels of national feeling appear to be quite stable in recent years (Coenders, Lubbers, and Scheeper 2020). They may not be so amenable to manipulation.

Our results are also consistent with a more negative conclusion. Lepore (2019) encourages scholars and public figures not to demonize nationalism. Krastev (2018) similarly argues that the lesson of recent populist movements for liberals is to not be seen as "anti-national". This creates a particular dilemma in the EU where parties who embrace the EU may be seen as traitors. It requires special care for parties to show that they are both proud of their nation and supporters of the EU, not to mention to attract voters whose national pride possibly makes them better citizens in the sense that we find here (Carey 2002). Mazower (2016) suggests the need to recover the possibility of a pro-European nationalism or a patriotic internationalism.

Another negative conclusion consistent with the results concerns the appeal of cosmopolitanism. It may appear that the alternative to nationalism is cosmopolitanism, but this does injustice to the historical 
record. Salam (2018) following McNeill (1985) argues that nationalism has not been the poorer alternative to a preexisting egalitarian cosmopolitanism (Tamir 2019). Historically, nationalism has been an egalitarian answer to hierarchical systems, often polyethnic hierarchies. Nationalism can serve to break down caste systems and unify distinctive groups. In fact, nationalism emerged partially under the influence of civic republicanism. Though our study did not include a test of this point, cosmopolitanism does not appear to have the motivational abilities of nationalism. It likely does not produce citizens committed to active and allegiant citizenship to the same extent insofar as most of the elements of this sort of citizenship are based at the national level. This suggests that cosmopolitan identities may not be the proper response to nationalism.

This embrace of nationalism naturally has its dangers. As previous work has shown, encouraging nationalism, or the wrong kind of nationalism, can have negative effects on tolerance of minorities, migrants, and foreigners and support of an open economy or the EU. Most disturbingly, it has been linked with international conflict (O’Leary and Sambanis 2018).

Future work on this subject should thus take care to confirm our findings in more rigorous ways. In the first place, scholars could conduct experimental work in the manner of Levendusky (2018) where he primes different aspects of national feeling to investigate their consequences for citizenship. Levendusky's work shows that priming national pride lowers affective polarization. One could investigate what sort of primes affect different aspects of citizenship. Similarly, scholars might study natural experiments where national feeling increases for exogenous reasons, for example, sports victories a la Bertoli (2017).

Further, scholars should investigate heterogeneities in the effect of national feeling. Does it work in different ways in different contexts as we found here for the differences between Western Europe and the postcommunist region? For example, does migration or diversity produce more negative effects as Putnam (2007) finds? We performed a test with multi-level models to see whether the size of migration flows or the percentage of foreign-born made a difference, but we did not find significant results.

There may also be heterogeneities in types of national feeling. Bonikowski (ND), for example, suggests that there are more nuanced types than ethnic and civic national identity, which might be associated with different forms of citizenship. Along this line, one could consider whether these results extend to the developing world where nationalism has often served different and anti-imperialist functions (Anderson 1987). Finally, scholars could further investigate why different forms and degrees of national feeling emerge in different places and times. This would help to determine what sort of policies could help to encourage better citizenship. 


\section{References}

Allport, Gordon. 1954. The nature of prejudice. Garden City: Doubleday.

Anderson, Benedict. 1987. Imagined communities: reflections on the origin and spread of nationalism. London: Verso.

Beissinger, Mark R. 2002. Nationalist mobilization and the collapse of the Soviet State. Cambridge University Press.

Bertoli, Andrew D. 2017. "Nationalism and Conflict: Lessons from International Sports." International Studies Quarterly 61(4): 835-849.

Bonikowski, Bart. ND. "Schemas of the Nation in Modern Democracies." Working Paper, Harvard University.

Brewer, Marilynn. 1999. “The Psychology of Prejudice: In-Group Love or Out-Group Hate?” Journal of Social Issues 55(3): 429-444.

Bunce, Valerie. 1999. Subversive institutions: The design and the destruction of socialism and the state. New York: Cambridge University Press.

Carey, Sean. 2002. "Undivided loyalties: is national identity an obstacle to European integration?" European union politics 3(4): 387-413.

Coenders, Marcel, Marcel Lubbers, and Peer Scheepers. 2020. "Nationalism in Europe: Trends and Cross-national Differences in Public Opinion." European Review, Online First.

Cowen, Tyler. 2019. "Don’t Let Trump Win All the Nationalists." Bloomberg.com, 30 May 2019. https://www.bloomberg.com/opinion/articles/2019-05-30/practical-nationalism-is-a-new-ideologyfor-a-new-political-era

Darden, Keith, and Anna Grzymala-Busse. 2006. "The great divide: Literacy, nationalism, and the communist collapse." World Politics 59(1): 83-115.

de Figueiredo, Jr., Rui J.P., and Zachary Elkins. 2003. "Are patriots bigots? An inquiry into the vices of in-group pride." American Journal of Political Science 47(1): 171-188.

Dinesen, Peter Thisted, Merlin Schaeffer, and Kim Mannemar Sønderskov. 2020. "Ethnic diversity and social trust: A narrative and meta-analytical review." Annual Review of Political Science 23: 441465 .

EVS. 2020. European Values Study 2017: Integrated Dataset (EVS 2017). GESIS Data Archive, Cologne. ZA7500 Data file Version 3.0.0, https://doi.org/10.4232/1.13511

EVS. 2011. European Values Study 2008: Integrated Dataset (EVS 2008). GESIS Data Archive, Cologne. ZA4800 Data file version 3.0.0, doi:10.4232/1.11004

Feldman, Naomi, and Joel Slemrod. 2009. "War and Taxation." In Isaac William Martin, Ajay K. Mehrotra, and Monica Prasad, eds. The new fiscal sociology: Taxation in comparative and historical perspective. New York: Cambridge University Press.

Gans, Chaim. 2003. The Limits of Nationalism. Cambridge: Cambridge University Press.

Geys, Benny and Kai A. Konrad. 2016. "Patriotism and Taxation." Max Planck Institute for Tax Law and Public Finance Working Paper 2016 - 11.

Gustavsson, Gina, and David Miller, eds. 2020. Liberal Nationalism and Its Critics: Normative and Empirical Questions. Oxford: Oxford University Press.

Howard, Marc Morjé. 2003. The weakness of civil society in post-communist Europe. Cambridge University Press. 
Huddy, Leonie and Alessandro Del Ponte. 2019. "National Identity, Pride, and Chauvinism - Their Origins and Consequences for Globalization Attitudes." In Gina Gustavsson and David Miller, eds., Liberal Nationalism and Its Critics: Normative and Empirical Questions. Oxford: Oxford University Press.

Huddy, Leonie and Nadia Khatib. 2007. "American patriotism, national identity, and political involvement." American Journal of Political Science 51(1): 63-77.

Janmaat, J. G. 2006. "Popular conceptions of nationhood in old and new European member states. Partial support for the ethnic-civic framework.” Ethnic and Racial Studies 29(1): 50-78.

Johnston, R. Richard, Keith Banting, Will Kymlicka and Stuart Soroka. 2010. "National identity and support for the welfare state." Canadian Journal of Political Science 43(2): 349-377.

Kateb, George. 2006. Patriotism and other mistakes. New Haven: Yale University Press.

Kohn, Hans. 1944. The Idea of Nationalism: A Study in Its Origins and Background. New York: Macmillan.

Kostelka, Filip. 2017. "Does democratic consolidation lead to a decline in voter turnout? Global evidence since 1939." American Political Science Review 111(4): 653-667.

Krastev, Ivan. 2018. "Central Europe is a lesson to liberals: don't be anti-nationalist." The Guardian, 11 July.

Kunovich, Robert M. 2009. "The sources and consequences of national identification." American Sociological Review 74(4): 573-593.

Lepore, Jill. 2019. This America: The Case for the Nation. New York: W. W. Norton \& Company.

Levendusky, Matthew S. 2018. "Americans, not partisans: Can priming American national identity reduce affective polarization?" The Journal of Politics 80(1): 59-70.

Lubbers, Marcel and Marcel Coenders. 2017. "Nationalistic attitudes and voting for the radical right in Europe." European Union Politics 18(1): 98-118.

Mazower, Mark. 2016. "Trump, Le Pen, and the Enduring Appeal of Nationalism." Financial Times, April 29.

McNeill, William. 1985. Polyethnicity and National Unity in World History. Toronto: University of Toronto Press.

Milanovic, Branko. 2017. "Democracy of Convenience, Not of Choice: Why Is Eastern Europe Different", http://glineq.blogspot.com/2017/12/democracy-of-convenience-not-of-choice.html.

Mill, John Stuart. 2010. Considerations on Representative Government. Cambridge: Cambridge UniversityPress.

Miller, David. 1995. On Nationalism. Oxford: Oxford University Press.

Müller-Peters, Anke. 1998. "The significance of national pride and national identity to the attitude toward the single European currency: A Europe-wide comparison." Journal of economic psychology 19(6): 701-719.

O'Leary, Brendan, and Nicholas Sambanis. 2018. "Nationalism and international security." In Alexandra Greciu and William C. Wohlforth, eds., The Oxford Handbook of International Security. Oxford: Oxford University Press.

Pop-Eleches, Grigore, and Joshua A. Tucker. 2017. Communism's shadow: Historical legacies and contemporary political attitudes. Princeton University Press, 2017. 
Putnam, Robert D. 2007. "E pluribus unum: Diversity and community in the twenty-first century. The 2006 Johan Skytte Prize Lecture." Scandinavian political studies 30(2): 137-174.

Putnam, Robert D., Robert Leonardi, and Raffaella Y. Nanetti. 1994. Making democracy work: Civic traditions in modern Italy. Princeton: Princeton University Press.

Rustow, Dankwart A. 1970. "Transitions to democracy: Toward a dynamic model." Comparative Politics 2(3): 337-363.

Salam, Reihan. 2018. "The Virtues of Nationalism." The Atlantic, 10 November.

Shulman, Stephen. 2002. "Challenging the civic/ethnic and West/East dichotomies in the study of nationalism." Comparative political studies 35(5): 554-585.

Subotic, Jelena. 2019. Yellow Star, Red Star: Holocaust Remembrance after Communism. Ithaca: Cornell University Press.

Tajfel, Henri. 1981. Human groups and social categories: Studies in social psychology. Cambridge: Cambridge University Press.

Tamir, Yael. 2019. "Not so civic: Is there a difference between ethnic and civic nationalism?" Annual Review of Political Science 22: 419-434.

Terry, Deborah J., and Michael A. Hogg. 1996. "Group norms and the attitude-behavior relationship: A role for group identification." Personality and social psychology bulletin 22(8): 776-793.

Van Deth, Jan W., José Ramón Montero, and Anders Westholm, eds. 2017. Citizenship and involvement in European democracies: A comparative analysis. London: Routledge.

Verba, Sidney, and Gabriel Almond. 1963. The civic culture: Political attitudes and democracy in five nations. Princeton: Princeton University Press.

Viroli, Maurizio. 1995. For love of country: An essay on patriotism and nationalism. Clarendon Press.

Weber, Eugen. 1976. Peasants into Frenchmen: the modernization of rural France, 1870-1914. Palo Alto: Stanford University Press.

Wright, Matthew and Tim Reeskens. 2013. "Of what cloth are the ties that bind? National identity and support for the welfare state across 29 European countries." Journal of European Public Policy 20(10): 1443-1463.

Yack, Bernard. 2012. Nationalism and the moral psychology of community. Chicago: University of Chicago Press 


\section{Appendix}

\section{Appendix Table A1: Question Wording and Coding, 2017}

\begin{tabular}{|c|c|}
\hline Variable & Question wording and coding \\
\hline Tax & $\begin{array}{l}\text { Please tell me for each of the following whether you think it can always } \\
\text { be justified, never be justified, or something in between. (1) always... } \\
\text { (10) never (original coding reversed) } \\
\text { Cheating on tax if you have the chance }\end{array}$ \\
\hline Bribe & $\begin{array}{l}\text { Please tell me for each of the following whether you think it can always } \\
\text { be justified, never be justified, or something in between. (1) always... } \\
\text { (10) never (original coding reversed) } \\
\text { Someone accepting a bribe in the course of their duties }\end{array}$ \\
\hline Transport & $\begin{array}{l}\text { Please tell me for each of the following whether you think it can always } \\
\text { be justified, never be justified, or something in between. (1) always... } \\
\text { (10) never (original coding reversed) } \\
\text { Avoiding a fare on public transport }\end{array}$ \\
\hline Benefits & $\begin{array}{l}\text { Please tell me for each of the following whether you think it can always } \\
\text { be justified, never be justified, or something in between. (1) always... } \\
\text { (10) never (original coding reversed) } \\
\text { Claiming state benefits which you are not entitled to }\end{array}$ \\
\hline Democracy & $\begin{array}{l}\text { How important is it for you to live in a country that is governed } \\
\text { democratically? On this scale where } 1 \text { means it is "not at all important" } \\
\text { and } 10 \text { means "absolutely important" what position would you choose? }\end{array}$ \\
\hline $\begin{array}{l}\text { Satisfaction with } \\
\text { political system }\end{array}$ & $\begin{array}{l}\text { On a scale from } 1 \text { to } 10 \text { where " } 1 \text { " is "not satisfied at all" and " } 10 \text { " is } \\
\text { "completely satisfied", how satisfied are you with how the political } \\
\text { system is functioning in your country these days? }\end{array}$ \\
\hline Vote & $\begin{array}{l}\text { When elections take place, do you vote (3) always, (2) usually or (1) } \\
\text { never? (original coding reversed) } \\
\text { Please tell me separately for each of the following levels; } \\
\text { - National } \\
\text { - Local }\end{array}$ \\
\hline Follow politics & $\begin{array}{l}\text { how often do you follow politics (1) never, (2) less often, (3) once or } \\
\text { twice a week, (4) several times a week (5) every day (original coding } \\
\text { reversed) } \\
\text { - on television } \\
\text { - on the radio } \\
\text { - in the daily papers } \\
\text { - on social media }\end{array}$ \\
\hline Volunteering & $\begin{array}{l}\text { Did you do voluntary work in the last } 6 \text { months? (original coding } \\
\text { reversed) } \\
\text { (0) No } \\
\text { (1) Yes }\end{array}$ \\
\hline $\begin{array}{l}\text { Voluntary } \\
\text { organization }\end{array}$ & $\begin{array}{l}\text { For each of the following voluntary organisations, please indicate } \\
\text { which, if any, do you belong to. } \\
\text { - Religious or church organisations } \\
\text { - Education, arts, music or cultural activities } \\
\text { - Trade unions }\end{array}$ \\
\hline
\end{tabular}




\begin{tabular}{|c|c|}
\hline & $\begin{array}{l}\text { - } \text { Political parties or groups } \\
\text { - } \text { Conservation, the environment, ecology, animal rights } \\
\text { - } \text { Professional associations } \\
\text { - } \text { Sports or recreation } \\
\text { - Humanitarian or charitable organization } \\
\text { - Consumer organization } \\
\text { - Self-help group, mutual aid group } \\
\text { - } \text { Other groups }\end{array}$ \\
\hline Trust & $\begin{array}{l}\text { Generally speaking, would you say that most people (1) can be trusted } \\
\text { or that }(0) \text { you can't be too careful in dealing with people? (original } \\
\text { coding reversed) }\end{array}$ \\
\hline Fight & $\begin{array}{l}\text { Of course, we all hope that there will not be another war, but if it were } \\
\text { to come to that, would you be willing to fight for your country? } \\
\text { (1) yes, (0) no }\end{array}$ \\
\hline $\begin{array}{l}\text { Ethnic } \\
\text { nationalism }\end{array}$ & $\begin{array}{l}\text { Please indicate how important this is to be truly [NATIONALITY]: To } \\
\text { have [COUNTRY]'s ancestry. (original coding reversed) } \\
\text { (1) not at all important, (2) not important, (3) quite important, (4) } \\
\text { very important }\end{array}$ \\
\hline Close to country & $\begin{array}{l}\text { How close do you feel to [country]? (original coding reversed) } \\
\text { (1) not close at all, (2) not very close, (3) close, (4) very close }\end{array}$ \\
\hline $\begin{array}{l}\text { Proud to be } \\
\text { citizen }\end{array}$ & $\begin{array}{l}\text { How proud are you to be a ... [country] citizen? (original coding } \\
\text { reversed) } \\
\text { (1) not at all proud, (2) not very proud, (3) quite proud, (4) very proud }\end{array}$ \\
\hline $\begin{array}{l}\text { University } \\
\text { educated }\end{array}$ & $\begin{array}{l}\text { Educational level of respondent: (1) Short-cycle tertiary, Bachelor or } \\
\text { equivalent, Master or equivalent, Doctoral or equivalent; }(0) \text { lower } \\
\text { educational level }\end{array}$ \\
\hline Age & Age of respondent \\
\hline Age squared & $\mathrm{Age}^{2}$ \\
\hline Female & Sex of respondent \\
\hline Income & $\begin{array}{l}\text { Here is a list of incomes and we would like to know in what group your } \\
\text { household is, counting all wages, salaries, pensions and other incomes } \\
\text { that come in. Just give the letter of the group your household falls into, } \\
\text { after taxes and other deductions. }\end{array}$ \\
\hline Unemployed & $\begin{array}{l}\text { Are you yourself gainfully employed at the moment or not? Please } \\
\text { select from the card the employment status that applies to you. } \\
\text { (1) unemployed (0) otherwise }\end{array}$ \\
\hline $\begin{array}{l}\text { Church } \\
\text { attendance }\end{array}$ & $\begin{array}{l}\text { Apart from weddings, funerals and christenings, about how often do you } \\
\text { attend religious services these days? } \\
\text { (1) more than once week (2) once a week (3) once a month (4) only on } \\
\text { specific holy days (5) once a year } 6 \text { less often ( } 7 \text { ) never, practically } \\
\text { never }\end{array}$ \\
\hline $\begin{array}{l}\text { Left-right } \\
\text { position }\end{array}$ & $\begin{array}{l}\text { In political matters, people talk of 'the leT' and 'the right'. How would } \\
\text { you place your views on this scale, generally speaking? } \\
\text { (1) the left (2) the right }\end{array}$ \\
\hline
\end{tabular}


Appendix Table A2: Descriptive statistics, 2017

\begin{tabular}{|l|c|c|c|c|}
\hline \multicolumn{1}{|l|}{ Variable } & Mean & S.D. & Min. & Max. \\
\hline \multicolumn{4}{|c|}{ Dependent variables } \\
\hline Tax & 8.889 & 2.036 & 1 & 10 \\
\hline Bribe & 9.416 & 1.484 & 1 & 10 \\
\hline Transport & 8.348 & 2.385 & 1 & 10 \\
\hline Benefits & 8.879 & 2.008 & 1 & 10 \\
\hline Democracy & 8.788 & 1.914 & 1 & 10 \\
\hline Satisfaction with political & 5.148 & 2.591 & 1 & 10 \\
system & \multicolumn{4}{l|}{} \\
\hline Vote & 4.103 & 1.261 & 1 & 5 \\
\hline Follow politics & 8.031 & 4.080 & 1 & 17 \\
\hline Volunteering & 0.230 & 0.420 & 0 & 1 \\
\hline Voluntary organization & 1.134 & 1.537 & 0 & 11 \\
\hline Trust & 0.391 & 0.488 & 0 & 1 \\
\hline Fight & 0.660 & 0.473 & 0 & 1 \\
\hline & Independent variables & & \\
\hline Ethnic nationalism & 2.751 & 0.976 & 1 & 4 \\
\hline Close to country & 3.310 & 0.704 & 1 & 4 \\
\hline Proud to be citizen & 3.355 & 0.732 & 1 & 4 \\
\hline University & 0.337 & 0.473 & 0 & 1 \\
\hline Age & 50.129 & 17.740 & 18 & 82 \\
\hline Age squared & 2827.692 & 1797.412 & 324 & 6724 \\
\hline Female & 0.549 & 0.497 & 0 & 1 \\
\hline Income & 5.084 & 2.741 & 1 & 10 \\
\hline Unemployed & 0.074 & 0.262 & 0 & 1 \\
\hline Church attendance & 5.020 & 1.851 & 1 & 7 \\
\hline Left-right position & 5.496 & 2.290 & 1 & 10 \\
\hline
\end{tabular}




\section{Appendix Table A3: Question Wording and Coding, 2008}

\begin{tabular}{|c|c|}
\hline Variable & Question wording and coding \\
\hline $\operatorname{Tax}$ & $\begin{array}{l}\text { Please tell me for each of the following whether you think it can always } \\
\text { be justified, never be justified, or something in between. (1) always... } \\
\text { (10) never (original coding reversed) } \\
\text { Cheating on tax if you have the chance }\end{array}$ \\
\hline Bribe & $\begin{array}{l}\text { Please tell me for each of the following whether you think it can always } \\
\text { be justified, never be justified, or something in between. (1) always... } \\
\text { (10) never (original coding reversed) } \\
\text { Someone accepting a bribe in the course of their duties }\end{array}$ \\
\hline Transport & $\begin{array}{l}\text { Please tell me for each of the following whether you think it can always } \\
\text { be justified, never be justified, or something in between. (1) always... } \\
\text { (10) never (original coding reversed) } \\
\text { Avoiding a fare on public transport }\end{array}$ \\
\hline Benefits & $\begin{array}{l}\text { Please tell me for each of the following whether you think it can always } \\
\text { be justified, never be justified, or something in between. (1) always... } \\
\text { (10) never (original coding reversed) } \\
\text { Claiming state benefits which you are not entitled to }\end{array}$ \\
\hline Democracy & $\begin{array}{l}\text { Democracy may have problems but it is better than any other form of } \\
\text { government. (1) disagree strongly, (2) disagree, (3) agree, (4) agree } \\
\text { strongly (original coding reversed) }\end{array}$ \\
\hline $\begin{array}{l}\text { Satisfaction with } \\
\text { democracy }\end{array}$ & $\begin{array}{l}\text { On the whole are you (4) very satisfied, (3) rather satisfied, (2) not very } \\
\text { satisfied or (1) not at all satisfied with the way democracy is developing } \\
\text { in our country? (original coding reversed) }\end{array}$ \\
\hline Vote & $\begin{array}{l}\text { Would you vote at a general election tomorrow? (0) no, (1) yes (original } \\
\text { coding reversed) }\end{array}$ \\
\hline Follow politics & $\begin{array}{l}\text { How often do you follow politics in the news on television or on the } \\
\text { radio or in the daily papers } \\
\text { (1) never, (2) less often, (3) once or twice a week, (4) several times a } \\
\text { week (5) every day (original coding reversed) }\end{array}$ \\
\hline $\begin{array}{l}\text { Voluntary } \\
\text { organization }\end{array}$ & $\begin{array}{l}\text { Please look carefully at the following list of voluntary organisations and } \\
\text { activities and say which, if any, you currently doing unpaid voluntary } \\
\text { work for. } \\
\text { - Religious or church organisations } \\
\text { - Education, arts, music or cultural activities } \\
\text { - Trade unions } \\
\text { - Local political action groups } \\
\text { - Human rights at home and abroad } \\
\text { - Conservation, the environment, ecology, animal rights } \\
\text { - Professional associations } \\
\text { - Youth work (scouts, guides, youth clubs) } \\
\text { - Sports or recreation } \\
\text { - Women's groups } \\
\text { - Peace movement } \\
\text { - Voluntary organization concerned with health } \\
\text { - Consumer groups }\end{array}$ \\
\hline
\end{tabular}




\begin{tabular}{|l|l|}
\hline Trust & \multicolumn{1}{|c|}{ Other groups } \\
\hline $\begin{array}{l}\text { Eenerally speaking, would you say that most people (1) can be trusted } \\
\text { or that (0) you can't be too careful in dealing with people? (original } \\
\text { coding reversed) }\end{array}$ \\
\hline $\begin{array}{l}\text { nationalism } \\
\text { Please indicate how important this is to be truly [NATIONALITY]: To } \\
\text { have [COUNTRY]'s ancestry. (original coding reversed) } \\
\text { (1) not at all important, (2) not important, (3) quite important, (4) } \\
\text { very important }\end{array}$ \\
\hline $\begin{array}{l}\text { University- } \\
\text { educated }\end{array}$ & $\begin{array}{l}\text { How proud are you to be a ... [country] citizen? (original coding } \\
\text { reversed) } \\
\text { (1) not at all proud, (2) not very proud, (3) quite proud, (4) very proud }\end{array}$ \\
\hline Age & $\begin{array}{l}\text { Educational level of respondent: (1) Short-cycle tertiary, Bachelor or } \\
\text { equivalent, Master or equivalent, Doctoral or equivalent; (0) lower } \\
\text { educational level }\end{array}$ \\
\hline Age squared & Age of respondent \\
\hline Female & Age 2 \\
\hline Income & Sex of respondent \\
\hline Unemployed & $\begin{array}{l}\text { Are you yourself gainfully employed at the moment or not? Please } \\
\text { select from the card the employment status that applies to you. } \\
\text { (1) unemployed (0) otherwise }\end{array}$ \\
\hline $\begin{array}{l}\text { Left-right } \\
\text { position } \\
\text { attendance }\end{array}$ & $\begin{array}{l}\text { Apart from weddings, funerals and christenings, about how often do you } \\
\text { attend religious services these days? } \\
\text { (1) more than once week (2) once a week (3) once a month (4) only on } \\
\text { specific holy days (5) once a year (6) less often (7) never, practically } \\
\text { never }\end{array}$ \\
\hline $\begin{array}{l}\text { In political matters, people talk of 'the left' and 'the right'. How would } \\
\text { you place your views on this scale, generally speaking? } \\
\text { (1) the left (2) the right }\end{array}$ \\
\hline
\end{tabular}


Appendix Table A4: Descriptive statistics, 2008

\begin{tabular}{|c|c|c|c|c|}
\hline Variable & Mean & S.D. & Min. & Max. \\
\hline \multicolumn{5}{|c|}{ Dependent variables } \\
\hline Tax & 8.717 & 2.110 & 1 & 10 \\
\hline Bribe & 9.223 & 1.635 & 1 & 10 \\
\hline Transport & 8.418 & 2.312 & 1 & 10 \\
\hline Benefits & 8.805 & 2.032 & 1 & 10 \\
\hline Democracy & 3.289 & 0.677 & 1 & 4 \\
\hline $\begin{array}{l}\text { Satisfaction with political } \\
\text { system }\end{array}$ & 2.364 & 0.791 & 1 & 4 \\
\hline Vote intention & 0.802 & 0.398 & 0 & 1 \\
\hline Follow politics & 3.818 & 1.317 & 1 & 5 \\
\hline Voluntary organization & 0.369 & 1.205 & 0 & 15 \\
\hline Trust & 0.299 & 0.458 & 0 & 1 \\
\hline \multicolumn{5}{|c|}{ Independent variables } \\
\hline Ethnic nationalism & 2.991 & 0.931 & 1 & 4 \\
\hline Proud to be citizen & 3.337 & 0.748 & 1 & 4 \\
\hline University-educated & 0.226 & 0.418 & 0 & 1 \\
\hline Age & 46.980 & 17.821 & 15 & 108 \\
\hline Age squared & 2524.799 & 1774.149 & 225 & 11664 \\
\hline Female & 0.555 & 0.496 & 0 & 1 \\
\hline Income & 1.943 & 0.798 & 1 & 3 \\
\hline Unemployed & 0.099 & 0.298 & 0 & 1 \\
\hline Church attendance & 4.570 & 1.938 & 1 & 7 \\
\hline Left-right position & 5.467 & 2.221 & 1 & 10 \\
\hline
\end{tabular}


Appendix Table A5: Country List, 2017

\begin{tabular}{|l|l|}
\hline Postcommunist & Non-communist \\
\hline Albania & Austria \\
\hline Azerbaijan & Denmark \\
\hline Armenia & Finland \\
\hline Bulgaria & France \\
\hline Belarus & Germany \\
\hline Croatia & Iceland \\
\hline Czech Republic & Italy \\
\hline Estonia & Netherlands \\
\hline Georgia & Norway \\
\hline Hungary & Spain \\
\hline Lithuania & Sweden \\
\hline Poland & Switzerland \\
\hline Romania & Great Britain \\
\hline Russia & \\
\hline Serbia & \\
\hline Slovak Republic & \\
\hline Slovenia & \\
\hline N respondents: 23,854 & N respondents: 24,150 \\
\hline
\end{tabular}


Appendix Table A6: Country List, 2008

\begin{tabular}{|l|l|}
\hline Postcommunist & Non-communist \\
\hline Albania & Austria \\
\hline Armenia & Belgium \\
\hline Bosnia and Herzegovina & Cyprus \\
\hline Bulgaria & Denmark \\
\hline Belarus & Finland \\
\hline Croatia & France \\
\hline Czech Republic & Germany \\
\hline Estonia & Greece \\
\hline Georgia & Iceland \\
\hline Hungary & Ireland \\
\hline Latvia & Italy \\
\hline Lithuania & Luxembourg \\
\hline Moldova & Malta \\
\hline Montenegro & Netherlands \\
\hline Poland & Norway \\
\hline Romania & Spain \\
\hline Russia & Sweden \\
\hline Serbia & Switzerland \\
\hline Slovak Republic & Turkey \\
\hline Slovenia & Great Britain \\
\hline Ukraine & Northern Ireland \\
\hline Macedonia & \\
\hline Kosovo & \\
\hline N respondents: 32,221 & N respondents: 27,606 \\
\hline
\end{tabular}


Are Nationalists Better Citizens?

Appendix Figure A1: Country Means of Closeness, 2017

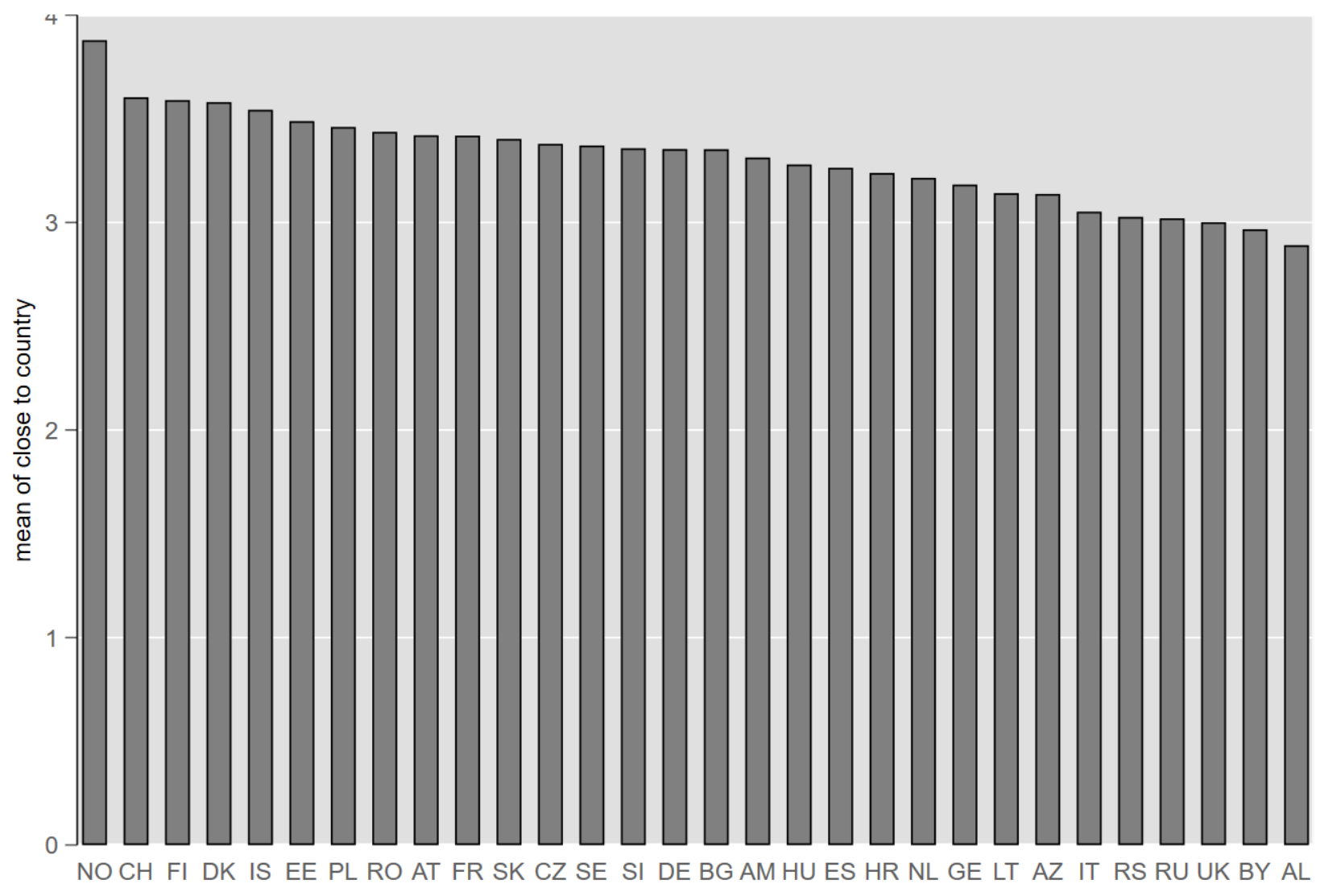


Appendix Figure A2: Country Means of Pride, 2017

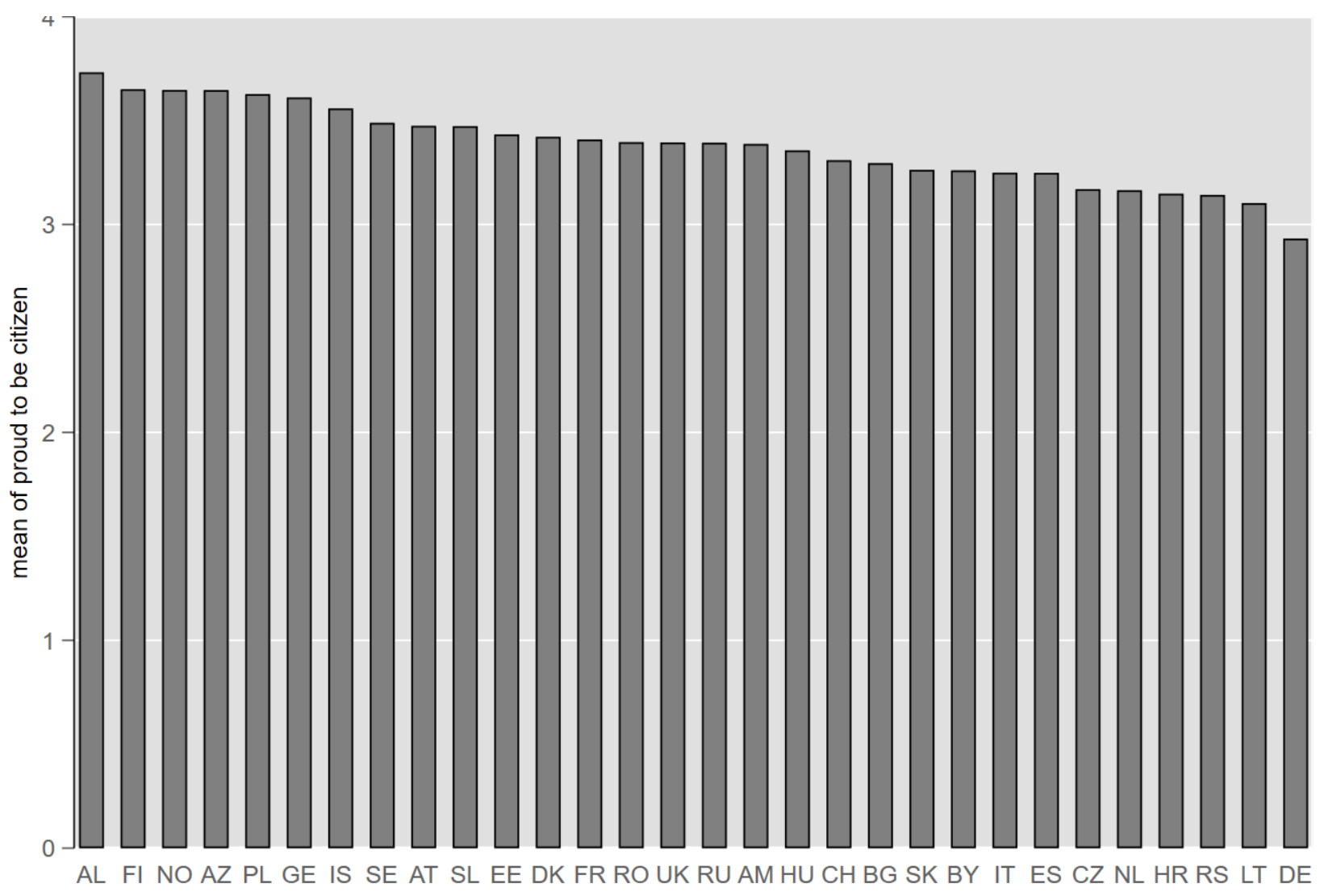


Appendix Figure A3: Country Means of Ethnic Nationalism, 2017

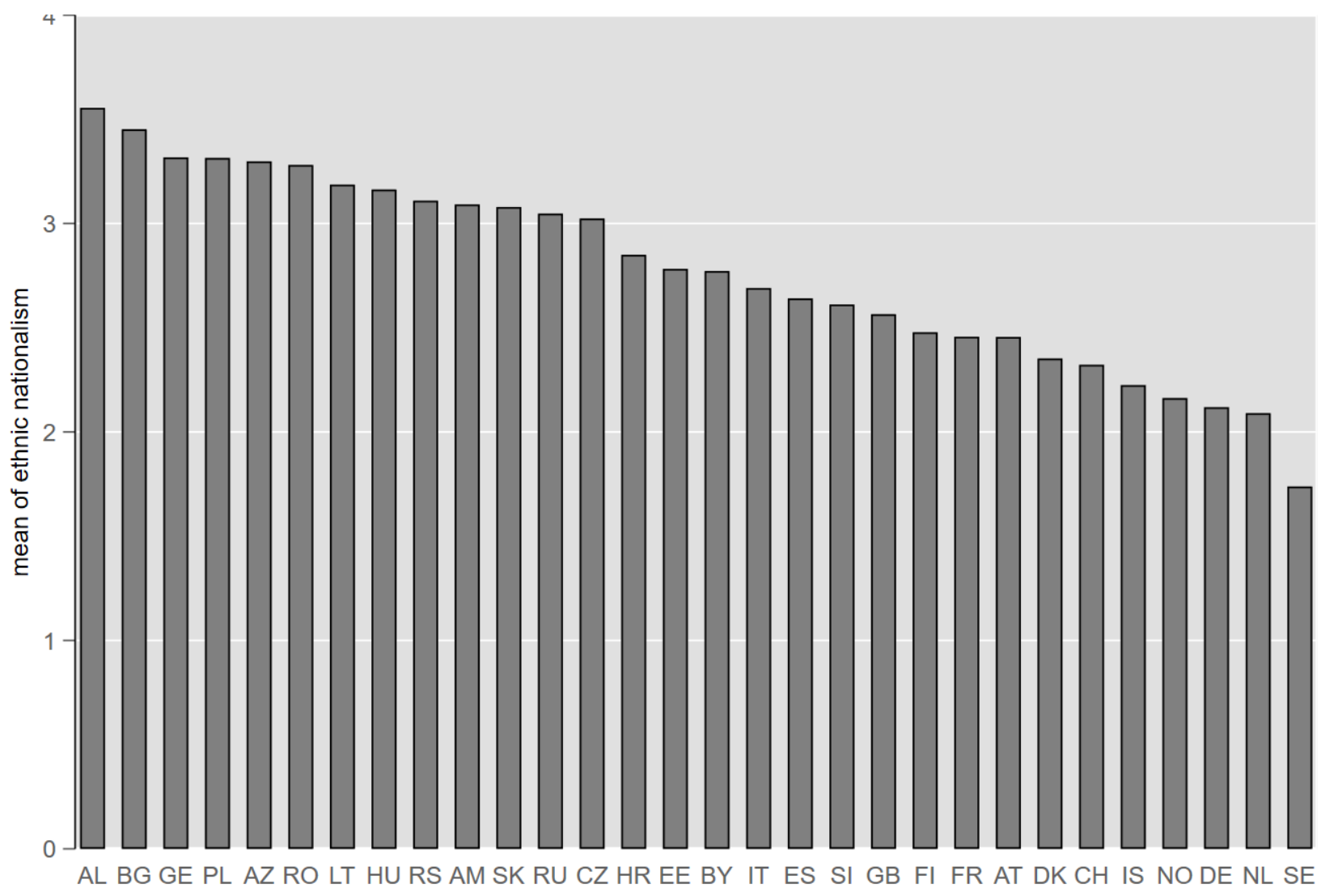

Additional appendices can be found online at http://europeangovernanceandpolitics.eui.eu/wpcontent/uploads/sites/4/2020/12/Are-Nationalists-Better-Citizens-Appendices-1.pdf 


\title{
Author contacts:
}

\section{Lenka Dražanová}

Migration Policy Centre, Robert Schuman Centre for Advanced Studies, EUI

Villa Malafrasca, Via Boccaccio 151

50133 Florence

Italy

Email: lenka.drazanova@eui.eu

\author{
Andrew Roberts \\ Department of Political Science \\ Northwestern University
}

Evanston, IL 60208

Email: aroberts@northwestern.edu 
With the support of the The European Commission supports the EUI through the European Union budget. This Erasmus+ Programme publication reflects the views only of the author(s), and the Commission cannot be held of the European Union responsible for any use which may be made of the information contained therein. 